\title{
Does the Commercial Bank's Loans Affect Economic Growth? Empirical Evidence for the Real Sector Economy in Kosovo (2005-2018)
}

\author{
Fisnik Morina ${ }^{1}$, Ercan Özen ${ }^{2 *}$ \\ ${ }^{1}$ Faculty of Business, University "Haxhi Zeka", Peja 30000, Republic of Kosovo \\ ${ }^{2}$ Department of Banking and Finance, Faculty of Applied Sciences, University of Uşak, Uşak 64200, Turkey
}

Corresponding Author Email: ercan.ozen@usak.edu.tr

https://doi.org/10.18280/ijsdp.150807

Received: 31 July 2020

Accepted: 2 October 2020

\section{Keywords:}

loans, economic growth, interest rates, inflation, the real sector

\begin{abstract}
The study aims to analyze the impact of credit policies of commercial banks on financing and development of the real sector of Kosovo's economy. In this context, some statistical and econometric models and techniques have been applied in order to test the impact of commercial banks through the lending process in the development of the real sector of Kosovo's economy for the period 2005-2018, using time series on a monthly basis. The empirical results of this study prove that commercial banks through the lending process have had a positive substantive impact on the development of the real sector in the economy of Kosovo. Economic development cannot happen without the development of the private sector and banks are the ones who can help and are helping in this regard. This study will provide a theoretical and practical analysis of contemporary forms of real sector lending, as well as, the importance of credit policy reform in financing and developing this sector and provide empirical evidence of how much bank loans have affected in the development of the real sector of Kosovo's economy.
\end{abstract}

\section{INTRODUCTION}

Kosovo became an independent state in 2008 and has developed a financial system able to create a sustainable economic and social life. Loan mechanisms generally allow a country to sustain investment capacity and economic development. So, we need to understand whether the loans are functioning adequately in a new Kosovo.

A developed economy is a value-producing economy, but allocating resources and funds properly dictates this development. Sustainable development should always be a profitable investment for the future. Therefore, an economy has two important sectors: The banking sector that provides financing and the real sector that realizes investments. These two sectors are ideally closely linked, but market irregularities, the development stage of each of these sectors and political factors dilute this connection. Kosovo's economy is still heavily influenced by informality and other irregularities that distort the principles of the market economy, so it is interesting to study the relationship between these two sectors to understand if their independent development affects each other. This study seeks in particular to ascertain, study and analyze how much the credit policies of commercial banks have influenced the development of the real sector of Kosovo's economy. To achieve the main goal of this study, data collection will be carried out based on the collection of data from secondary sources: publications of the Central Bank of Kosovo, World Bank, Kosovo Statistics Agency, Kosovo Banking Association, Ministry of Finance, International Monetary Fund, OECD, European Central Bank, etc. The processing of the data of the above-mentioned reports has been done by the STATA software program, specifically using linear regression, Fixed Effect, Random Effect, Hausman Taylor Regression and GMM modelling.

According to Wickell's [1] theory, lending has had little effect on economic growth within interest rates. If interest rates are below the rate of return on equity, entrepreneurs would borrow at the rate of money to buy capital goods that would drive a higher rate of economic growth. On the other hand, if interest rates are above the return on equity level, entrepreneurs will sell capital goods and actually keep the money while reducing economic growth.

Cracknell [2] argues that facilitating financial access provides impetus to strengthening the financial sector, which is a key player in economic growth and real sector development. Many European countries seem to have borrowed this argument and increased the real sector's approach to bank lending, applying for more financial facilities from banks to boost economic growth. However, there does not appear to be a positive automatic relationship between lending and economic growth.

The financial sector provides funding for the real economy. By acting as financial intermediaries, financial institutions play a key role in the real sector of the economy by transforming assets, facilitating risk management, financing trade, and enabling capital accumulation [3]. This is due to the fact that the financial sector enables the flow of the financial assets of the end savers in the liabilities of the end users of the financial funds, both within and between the national economies [4].

Boyreau-Debray [5] in his study analyzes the relationship between economic growth and financial intermediation in China by applying the traditional empirical framework to a panel data, which includes the time series method. A number 
of studies have analyzed economic growth patterns in Chinese provinces, with a focus on the role of economic opening, foreign direct investment, and infrastructure. Boyreau-Debray [5] presented the role of financial intermediation in the economic growth of Chinese provinces, although other authors have scarcely analyzed the impact of financial intermediation on the economic development of this country, which is surprising given the importance in terms of the impacts of economic policies and the challenges posed by increased competition in the financial sector that will follow China's accession to the World Trade Organization.

McPherson and Waller [6] show that even in a financially developed economy such as the United States, local banks affect the performance of the local economy. The results of the study consist of the fact that due to the fragmentation of the capital market, inequality in banking development is an important factor in local economic performance. The author concludes that China's financial development does not contribute to local economic performance, as shown by the insufficiency of the deposit ratio to GDP.

The empirical results from Boyreau-Debray's [5] study, determine the negative impact of public bank lending on the financial performance of businesses. So when controlling the size of state-owned corporations in the local economy, the negative impact of state-owned banks on economic growth is greatly reduced. That study suggests that improving the performance of the state-owned bank and increasing the distribution of financial resources would require reforming the public corporate sector and improving the economic climate at the local level.

The critical role of financial institutions in terms of economic growth and development cannot be overemphasized. For sustainable growth in any given economy, financial resources must be mobilized effectively and efficiently and allocated in such a way as to exploit synergies between human, material and managerial resources for optimal economic production. Many studies by various authors have shown that banks cannot always set high interest rates. Banks need to consider the problems of negative selection and moral risk, as it is very difficult to predict the type of borrower at the beginning of the credit relationship [7].

Arcand et al. [8] reveal that the ratio of financing and economic growth is negative for high-income countries, with a value of $110 \%$ private credit to GDP and negative relations between the financial sector and economic growth are significant at the level of $150 \%$ private credit to GDP. If banks set very high interest rates, they can trigger negative selection problems because high-risk borrowers are willing to accept these high interest rates on credit. These borrowers, after taking out a loan, are likely to engage in dangerous moral behavior or so-called moral damage to the borrower, as they are more likely to receive very dangerous projects or investments [9]. Based on the theoretical arguments of the authors Stiglitz and Weiss, it is common that in some cases we cannot discover if the interest rate set by banks is proportional to the risk of borrowers

A study by Borio and Zhu [10] states that the pro-cyclical behavior of credit probability estimates often provides a measure of immediate risk in the business environment. They investigated the impact of the business environment on credit expansion and concluded that the loss can be attributed to unforeseen business environment risks. Unforeseen changes in monetary policy that also affect stock prices can also affect risk perceptions and the private sector's willingness to face risks, making the business environment risk being too dependent on the country's monetary policy. Monetary policy can have strong results for commercial loans as banks' interest rates are likely to be higher in business environments with higher risk levels. Private sector businesses are also likely to be more vulnerable to borrowing if interest rates are high as this could reduce profit margins [11].

Jiménez et al. [12] also studied the lending behavior of European banks and found that Spanish banks provide more risky loans and reduce lending standards to lower interest rates. Also, Altunbas et al. [13] in their study find that banks are able to offer better interest rates and higher loans in less risky environments with minimal probability of delay. These studies find empirical evidence that tightening monetary policy is also likely to affect the profitability of banks as this will affect the bank yield curve, through rising interest rates, leading to lower credit and lower returns on borrowed capital.

Chodechai [9], in his studies identified the determining factors that affect interest rates, the volume of lending and the placement of collateral in the credit decision of banks, which are: "Banks must be careful in their decisions in relation to the lending price, as they cannot charge credit rates that are too low because interest income will not be enough to cover the cost of deposits, total expenses and loss of income by some non-paying borrowers. Furthermore, charging high credit rates can also create a situation of negative selection and moral risk problems for borrowers".

The study of Nwakoby and Ananwude [14] generally acknowledged that the intensification of financial instruments and institutions would greatly reduce transaction and information costs in an economy that affects interest rates on savings, investment decisions, and innovative technology. The capacity of commercial banks to provide potentially unlimited financing (domestic income) outside the savings of households and corporations provides the basis for the everexpanding productive entrepreneurial activity, causing great barriers to the process of economic growth. Besides, according to Son et al. [15], addition to other factors, education has a positive and important effect on economic growth.

This paper, in comparison with the studies of other authors, brings innovation since for deriving the empirical and econometric results of this study, five statistical tests and some analysis of linear trends have been applied through which has increased the stability and comparability of the results of this study.

This paper is organized in six sections. The first section presents the literature review based on studies by various authors. The second section presents a comparative analysis of the main financial indicators for the banking system in Kosovo. In the third part of this study are presented the scientific methodology and specification of the econometric model, while in the fourth part are elaborated descriptive statistics and correlation analysis. The fifth section presents the empirical findings of the study based on various statistical tests and analyzed through various econometric models. The last part of this study presents the conclusions and recommendations, based on the empirical findings of this research

Originality/Value: This scientific paper presents a real and original study, taking into account that all data are based on the financial and statistical reports of relevant institutions and the time period taken into account in this study is a convincing period for obtaining concrete results. Besides this, is the first paper investigating the relationship between bank loans and Gross Domestic Production (GDP) for Kosovo. 


\section{LITERATURE REVIEW}

One can see there are a lot of studies which investigated the relationship between bank loans and economic growth. For example, Obamuyi et al. [16] claim that there is a close relationship between commercial bank lending and economic production. This is because, usually, lending increases investment in goods and the provision of services that would logically increase a country's GDP. On the contrary, reduced lending by commercial banks would reduce investment in the production of goods and services that would in turn reduce GDP. This report summarizes a positive relationship between commercial bank lending and economic growth. In contrast, a study by Louzis et al. [17] showed that lending does not automatically affect economic growth. The contexts within which loans are provided are a contributing factor to the effect of lending on economic growth. This ratio was influenced by credit management by both commercial banks and borrowers.

Kelly et al. [18] conducted a study aimed at identifying and establishing the relationship between real sector loans and economic growth in Ireland, which had experienced a broader approach to credit. The real sector loan was defined as the loans granted to Irish private residents by all credit institutions that were resident in Ireland. The research was done for the period between 1983 and 1997. The findings showed that there is a strong positive relationship between real sector credit and economic growth.

Similar findings have been presented previously by Caporale et al. [19]. Their study was conducted to establish the link between economic growth and bank credit for countries that were new member states in the European Union between 1994 and 2007. These were ten countries in total. To establish this empirical relationship, the study resulted in a regression between the rate of economic growth and financial development measured by domestic credit indicators and specific macroeconomic indicators of the country, such as bank efficiency and stock market capitalization. Empirical findings from the study showed that there is a close link between economic growth and bank credit, in the sense that poor credit availability caused poor economic growth in these ten countries.

During the literature review process, the findings of many studies that have addressed the issue of the impact of credit on economic growth and the development of the real sector on the economies of different countries were analyzed. Authors such as Bezemer [20], Cojocaru et al. [21], Demirgüç-Kunt and Levine [22], Huang and Wang [23], Petrescu and Pop [24], Vurur and Ozen [25] have found causation from loans to GDP and many other studies have analyzed the effects of bank loans on economic growth for different countries.

The following table shows some studies of other authors who have analyzed the impact of bank loans on the economic growth of developing and developed countries. So, in the Table 1, in summary form, the empirical results of these studies in different periods of time are presented.

As can be seen from the results presented in the Table 1 above, we can conclude that all these studies have consistent, significant results and the findings are mixed. The table above presents, through meta-analysis, the empirical results of thirty studies of other authors in different countries of the world. Of the thirty studies, fifteen find that there is a positive correlation between bank lending and economic growth in developing countries, two declare a negative correlation and two other studies give mixed results.

As for the studies of different authors that have been conducted in developed countries, eleven of these studies found a positive relationship between bank loans and economic growth, four of them a negative relationship and three of these studies have come up with mixed results. It is worth noting that from this meta-analysis, over $90 \%$ of the analyzed studies consider a positive impact of bank loans on the economic growth of these countries.

Table 1. Summary of econometric results from studies of other authors

\begin{tabular}{|c|c|c|c|c|c|c|c|c|c|c|c|c|c|c|c|}
\hline \multicolumn{2}{|r|}{$\begin{array}{c}\text { Impact of bank loans on } \\
\text { economic growth }\end{array}$} & \multicolumn{3}{|c|}{$\begin{array}{c}\text { Developing } \\
\text { Countries }\end{array}$} & \multicolumn{3}{|c|}{$\begin{array}{l}\text { Developed } \\
\text { Countries }\end{array}$} & \multicolumn{2}{|c|}{$\begin{array}{c}\text { Impact of bank loans on } \\
\text { economic growth }\end{array}$} & \multicolumn{3}{|c|}{$\begin{array}{c}\text { Developing } \\
\text { Countries }\end{array}$} & \multicolumn{3}{|c|}{$\begin{array}{l}\text { Developed } \\
\text { Countries }\end{array}$} \\
\hline No & Author, Title of paper & $\mathrm{P}$ & $\mathrm{N}$ & $\mathrm{M}$ & $\mathrm{P}$ & $\mathrm{N}$ & $\mathrm{M}$ & No & Author, Title of paper & $\mathrm{P}$ & $\mathrm{N}$ & $\mathrm{M}$ & $\mathrm{P}$ & $\mathrm{N}$ & $\mathrm{M}$ \\
\hline 1 & $\begin{array}{l}\text { Garcia et al. [26] - Credit } \\
\text { Expansion in Emerging } \\
\text { Markets: Propeller of } \\
\text { Growth? }\end{array}$ & + & & + & & & & 5 & $\begin{array}{l}\text { Hacievliyagil \& Eksi [30] } \\
\text { - A micro based study on } \\
\text { bank credit and economic } \\
\text { growth: manufacturing } \\
\text { sub-sectors analysis }\end{array}$ & + & & & & & \\
\hline 2 & $\begin{array}{l}\text { Awad and Karaki [27] - The } \\
\text { impact of bank lending on } \\
\text { Palestine economic growth: } \\
\text { an econometric analysis of } \\
\text { time series data }\end{array}$ & + & & & & & & 6 & $\begin{array}{c}\text { Ciantar [31] - The impact } \\
\text { of bank lending on } \\
\text { economic growth in Malta }\end{array}$ & & & & + & & \\
\hline 3 & $\begin{array}{l}\text { Hanişoğlu and Azer [28]- } \\
\text { The Impact of Housing } \\
\text { Loans on Economic Growth } \\
\text { in Turkey: Times Series } \\
\text { Analysis for 2010-2015 } \\
\text { Period }\end{array}$ & + & & & & & & 7 & $\begin{array}{l}\text { Ramírez Guerra [32] - } \\
\text { The economic growth and } \\
\text { the banking credit in } \\
\text { Mexico: Granger } \\
\text { causality and short-term } \\
\text { effects, } 2001 \mathrm{Q} 1-2016 \mathrm{Q} 4\end{array}$ & + & & & & & \\
\hline 4 & $\begin{array}{l}\text { Cappiello et al. [29] - Do } \\
\text { bank loans and credit } \\
\text { standards have an effect on } \\
\text { output? A panel approach } \\
\text { for the Euro Area }\end{array}$ & & & & + & & + & 8 & $\begin{array}{l}\text { Devi [33] - The impact of } \\
\text { rural bank loans on } \\
\text { regional economic growth } \\
\text { and regional poverty in } \\
\text { Indonesia }\end{array}$ & + & & & & & \\
\hline
\end{tabular}


Table 1. Summary of econometric results from studies of other authors (Continued)

\begin{tabular}{|c|c|c|c|c|c|c|c|c|c|c|c|c|c|c|c|}
\hline \multicolumn{2}{|r|}{$\begin{array}{l}\text { Impact of bank loans on } \\
\text { economic growth }\end{array}$} & \multicolumn{3}{|c|}{$\begin{array}{l}\text { Developing } \\
\text { Countries }\end{array}$} & \multicolumn{3}{|c|}{$\begin{array}{l}\text { Developed } \\
\text { Countries }\end{array}$} & \multicolumn{2}{|c|}{$\begin{array}{l}\text { Impact of bank loans on } \\
\text { economic growth }\end{array}$} & \multicolumn{3}{|c|}{$\begin{array}{l}\text { Developing } \\
\text { Countries }\end{array}$} & \multicolumn{3}{|c|}{$\begin{array}{l}\text { Developed } \\
\text { Countries }\end{array}$} \\
\hline No & Author, Title of paper & $\mathrm{P}$ & $\mathrm{N}$ & $\mathrm{M}$ & $\mathrm{P}$ & $\mathrm{N}$ & $\mathrm{M}$ & No & Author, Title of paper & $\mathrm{P}$ & $\mathrm{N}$ & $\mathrm{M}$ & $\mathrm{P}$ & $\mathrm{N}$ & M \\
\hline 1 & $\begin{array}{l}\text { Černohorský [34] - Types } \\
\text { of bank loans and their } \\
\text { impact on economic } \\
\text { development: a case study } \\
\text { of the Czech Republic }\end{array}$ & & & & + & & + & 11 & $\begin{array}{c}\text { Ananzeh [43] - } \\
\text { Relationship between } \\
\text { bank credit and economic } \\
\text { growth: evidence from } \\
\text { Jordan }\end{array}$ & + & & + & & & \\
\hline 2 & $\begin{array}{l}\text { Levine and Zervos [35]- } \\
\text { Stock Markets, Banks, and } \\
\text { Economic Growth }\end{array}$ & & & & + & & & 12 & $\begin{array}{l}\text { Obamuyi et al. [16] - } \\
\text { Bank lrnfing, economic } \\
\text { growth and the } \\
\text { performance of the } \\
\text { manufacturing sector in } \\
\text { Nigeria" }\end{array}$ & + & & & & & \\
\hline 3 & $\begin{array}{l}\text { Armeanu et al. [36] - The } \\
\text { Credit Impact on the } \\
\text { Economic Growth }\end{array}$ & & & & + & & & 13 & $\begin{array}{l}\text { Louzis et al. [17]- } \\
\text { Macroeconomic and } \\
\text { bank-specific } \\
\text { determinants of non- } \\
\text { performing loans in } \\
\text { Greece: a comparative } \\
\text { study of mortgage, } \\
\text { business and consumer } \\
\text { loan portfolios }\end{array}$ & & & & & & + \\
\hline 4 & $\begin{array}{l}\text { Kelly et al. [18] - Exploring } \\
\text { the Steady-State } \\
\text { Relationship between Credit } \\
\text { and GDP for a Small Open } \\
\text { Economy: the Case of } \\
\text { Ireland }\end{array}$ & & & & + & & & 14 & $\begin{array}{l}\text { Caporole et al. [19] - } \\
\text { Financial Development } \\
\text { and Economic Growth: } \\
\text { Evidence from Ten New } \\
\text { EU Members }\end{array}$ & & & & + & & \\
\hline 5 & $\begin{array}{l}\text { Ermişoğlu et al. [37] - GDP } \\
\text { Growth and Credit Data }\end{array}$ & + & & & & & & 15 & $\begin{array}{l}\text { Bezemer et al. [20] - Is } \\
\text { the financial development } \\
\text { bad for growth. }\end{array}$ & + & & & + & & \\
\hline 6 & $\begin{array}{c}\text { Mian et al. [38] - Household } \\
\text { Debt and Business Cycles } \\
\text { Worldwide }\end{array}$ & & & & & - & & 16 & $\begin{array}{l}\text { Demirgüç-Kunt and } \\
\text { Levine [22] - Finance, } \\
\text { Financial Sector Policies, } \\
\text { and Long-Run Growth }\end{array}$ & + & & & + & & \\
\hline 7 & $\begin{array}{l}\text { Ibáñez-Hernández et al. } \\
\text { [39] - Countercyclical } \\
\text { capital buffers: credit-to- } \\
\text { GDP ratio versus credit } \\
\text { growth }\end{array}$ & & & & & - & & 17 & $\begin{array}{l}\text { Huang and Wang [23] - } \\
\text { Does Financial } \\
\text { Repression Inhibit } \\
\text { Economic Growth? } \\
\text { Empirical Examination of } \\
\text { China's Reform } \\
\text { Experience }\end{array}$ & + & & & & & \\
\hline 8 & $\begin{array}{c}\text { Mamman and Hashim [40] - } \\
\text { Impact of Bank Lending on } \\
\text { Economic Growth in } \\
\text { Nigeria }\end{array}$ & & - & & & & & 18 & $\begin{array}{l}\text { Petrescu and Pop [24] - } \\
\text { The Influence of Lending } \\
\text { Activity on Economic } \\
\text { Growth in Romania }\end{array}$ & & & & + & & \\
\hline 9 & $\begin{array}{l}\text { Vaithilingam et al. [41] - } \\
\text { Bank Lending and } \\
\text { Economic Growth in } \\
\text { Malaysia }\end{array}$ & + & & & & & & 19 & $\begin{array}{l}\text { Vurur and Özen [25] - } \\
\text { The Examination of the } \\
\text { Relationship Between } \\
\text { Deposits Bank Credits } \\
\text { and Economic Growth in } \\
\text { Turkey }\end{array}$ & + & & & & & \\
\hline 10 & $\begin{array}{c}\text { Leitão [42] - Bank Credit } \\
\text { and Economic Growth: A } \\
\text { Dynamic Panel Data } \\
\text { Analysis }\end{array}$ & & & & & - & & 20 & $\begin{array}{l}\text { Cojocaru et al. [21] - } \\
\text { Financial Development } \\
\text { and Economic Growth in } \\
\text { Transition Economies: } \\
\text { Empirical Evidence from } \\
\text { the CEE and CIS } \\
\text { Countries }\end{array}$ & + & & & & & \\
\hline
\end{tabular}

Explanation: The symbols $P, N$ and $M$ represent these initials: $P$ - positive, $N$ - negative and $M$ - mixed.

Commercial bank loans allow greater economic growth through investment and higher consumption, while greater economic growth stimulates credit volume growth as economic activity increases collateral values and improves borrowers' financial capacity through falling unemployment.

So, through the results of these studies we can conclude that in most countries, bank loans have a positive impact on economic growth, an impact that depends not only on the stage of economic development of the country, but also on the type of bank loans that are analyzed in these studies.

In some countries, there has been a negative impact, due to the fact that we have a mutual influence between bank loans and GDP, as economic growth also affects the volume of loans. In some studies by other authors we have mixed findings, 
especially during the period of the banking financial crisis 2007 - 2009, where the impact of bank loans on the real sector of the economy of these countries is very small and even during this period and after financial crisis we have many dilemmas regarding the effects that these loans have had on the economic activity of these countries.

Given that a large part of the studies has consistent results and have identified a positive correlation between bank loans and economic growth, this has been a major motive why we chose this topic for study.

\section{BANKING, FINANCE AND FUNDAMENTAL ECONOMICS INDICATORS IN KOSOVO}

Commercial banks in Kosovo serve the citizens and businesses of Kosovo by offering a wide range of financial services. These financial institutions make it possible for businesses to start and expand their activities, increase employment and provide better services to their customers. Banks also help households achieve their goals by enabling them to finance their housing, fund their education, or afford other necessary expenses.

Today, 10 commercial banks operate in Kosovo and constitute $65 \%$ of the total assets of the financial sector. Their products and services include bank accounts, loans, local and international payments, bank cards, bank guarantees, credit cards and e-banking. Access to the services of these banks is enabled currently through 217 branches and sub-branches, 497 ATMs and 13,769 POS and 303,602 e-banking accounts.

Their activity is dominated by loans, the maturity of which can be up to 15 years, depending on the type of loan. Of the total loans, which amount to 3,031.9 million euros, loans to enterprises constitute $63.3 \%$ while loans to individuals / households stand at $36.5 \%$. Most of these loans are absorbed by commercial sector enterprises (44.3 percent of enterprise loans), while the industrial sector (including mining, manufacturing, energy and construction) accounts for $25.8 \%$ of total enterprise loans. The agricultural sector currently accounts for $3.7 \%$ of total loans to enterprises.

The activity of the banking sector since the beginning of its operation continues to be financed mainly by local sources of funding, which has led the banking sector to have low sensitivity to changes in financing conditions in the external sector during the financial crisis. Although the banking sector in Kosovo is dominated by local sources of financing in the structure of liabilities, in recent years there has been a tendency to increase the use of external financing, which will increase the capacity of banks to expand lending.

In 2010, deposits reached 1.8 billion euros, an annual increase of $15.8 \%$. Deposits in the banking sector in Kosovo in 2010 were less sensitive to the effects of the financial crisis because the banking sector is dominated by deposits generated within the country. The amount of deposits collected by households in 2010 amounted to 1.13 billion euros $(65 \%$ of total deposits), while the value of corporate deposits reached 306.2 million euros or $17.5 \%$ of total deposits [44]

The total value of deposits collected in 2011 was 1.9 billion euros, marking an annual increase of $11.8 \%$. The slowdown in deposit growth since 2008 was due to declining government deposits in commercial banks. The value of household deposits in 2011 was 1.4 billion euros or $69.2 \%$, while the total amount of corporate deposits amounted to 380 million euros or $19 \%$ of total deposits [45].

The year 2012 is characterized by an annual increase in deposits compared to the previous year. The total value of deposits in 2012 amounted to 2.1 billion euros. This slowdown in the growth of total deposits in the banking sector in Kosovo is natural because in the first years of the functioning of the banking system they had a greater flow of savings which were kept outside the banking system and then included as deposits of commercial banks [46].

Table 2 presents the percentage of deposits in the banking sector in Kosovo for the period 2005 - 2018.

The total amount of deposits in 2013 was 2.2 billion euros, an annual increase of $4.4 \%$. This reduced growth is due to the decline in deposits of private and public enterprises, as well as the slow pace of growth of household deposits. Deposits of households reached the value of 1.6 billion euros or $74.8 \%$ of total deposits while enterprise deposits had a value of 449.4 million euros or $15.6 \%$ participation in the total value of deposits.

The slight increase in household deposits during 2013 can be attributed to the increase in remittances, the compensation of workers from abroad, and the slight increase in interest rates on deposits from commercial banks [47]. The total value of deposits in the banking sector in 2014 was 2.42 billion euros, with an annual increase of $10 \%$. During 2014 they had a greater trend of deposit growth, despite the fact that we had a significant decline in interest rates on deposits. This situation highlights that the banking system in Kosovo has a high stability of deposits, participating with $79.1 \%$ of the total liabilities of this sector [48].

Table 2. Percentage of deposits in the banking system in Kosovo (2005-2018)

\begin{tabular}{ccccc}
\hline Year & Family Economies & Enterprises & Non-residents & Government \\
\hline 2005 & $54.00 \%$ & $44.00 \%$ & $1.80 \%$ & $0.20 \%$ \\
2006 & $56.70 \%$ & $37.00 \%$ & $5.90 \%$ & $1.00 \%$ \\
2007 & $63.90 \%$ & $32.30 \%$ & $3.30 \%$ & $0.50 \%$ \\
2008 & $58.80 \%$ & $32.20 \%$ & $6.50 \%$ & $2.50 \%$ \\
2009 & $60.00 \%$ & $31.40 \%$ & $6.10 \%$ & $2.50 \%$ \\
2010 & $65.00 \%$ & $17.50 \%$ & $4.30 \%$ & $6.00 \%$ \\
2011 & $69.20 \%$ & $19.00 \%$ & $5.40 \%$ & $6.40 \%$ \\
2012 & $72.10 \%$ & $23.00 \%$ & $3.60 \%$ & $1.30 \%$ \\
2013 & $74.80 \%$ & $15.60 \%$ & $4.10 \%$ & $5.50 \%$ \\
2014 & $74.20 \%$ & $20.80 \%$ & $5.40 \%$ & $1.60 \%$ \\
2015 & $74.00 \%$ & $25.90 \%$ & $3.60 \%$ & $1.50 \%$ \\
2016 & $74.40 \%$ & $20.80 \%$ & $3.80 \%$ & $1.00 \%$ \\
2017 & $73.10 \%$ & $22.10 \%$ & $3.70 \%$ & $1.10 \%$ \\
2018 & $69.40 \%$ & $27.00 \%$ & $3.10 \%$ & $0.48 \%$ \\
\hline
\end{tabular}


The year 2015 was accompanied by a deposit level of 2.57 billion euros, marking an annual increase of $6.3 \%$. According to the maturity date, the deposit structure had undergone significant changes compared to the previous two years. The time deposits dominated the deposit structure in 2015, with a share of $50.1 \%$ in total deposits [49].

Figure 1 graphically presents the structure of deposits in the banking sector in Kosovo for the period $2005-2018$.

In 2016, deposits in the banking sector in Kosovo amounted to 2.69 billion euros, marking an annual increase of $4.6 \%$. Even during 2016, household deposits continue to be the most stable source of financing compared to other financing channels. The structure of liabilities of the banking sector in 2017 is dominated by deposits, which account for $78.7 \%$ of total liabilities. The total value of these deposits amounted to 2.89 billion euros, with an annual increase of $7.2 \%$. Deposits of households during 2017 have increased annually by $5.4 \%$, while corporate deposits have increased annually by $14.1 \%$ [50].

Savings of households, in the form of time deposits and transferable deposits have increased during 2018. This increase in deposits has come as a result of the gradual increase of the interest rate on deposits which has had effects on reducing the opportunity cost of holding savings and maturity of assets. In 2018, deposits increased by $8.7 \%$ more than in 2017, and reached the level of 3.36 billion euros [51]. The value of the average amount of deposits in the banking system in Kosovo (2005-2018) is 1,911.66 or 1.9 billion euros, a value that shows that commercial banks in Kosovo during this period have large amounts of deposits that can serve as important sources for granting bank loans. The banking sector in Kosovo from 2005 to 2009 was characterized by new inflows of commercial banks, e.g. in 2007, the Central Bank licensed two commercial banks to operate in Kosovo (BKT and Komercijalna Banka), while in 2008 TEB Banka and NLB Prishtina were licensed. The entry of new commercial banks in Kosovo also changed the structure of loans in the banking sector. Kosovo banking sector assets are dominated by loans issued by commercial banks. In the following analysis, we will review the percentage of loans for the period 2005 - 2017 and the sectoral distribution of loans by years. In 2010, loans provided by commercial banks in Kosovo reached a value of 1.4 billion euros and marked an annual increase of $9.6 \%$. According to the data in Figure 2 credit portfolio in 2010 is dominated by loans granted to enterprises $(70.9 \%)$, while loans to households reach a value of up to $29.1 \%$. Table 3 presents the percentage of loans in the banking sector in Kosovo for the period 2005-2018.

If we compare these data with the previous year, we can say that loans to households have decreased by $4.8 \%$. During this period, there has been a reluctance of banks to greatly expand lending to enterprises, which reflects the uncertainty of banks about the performance of this sector [44]. Commercial lending activity of commercial banks continues to be one of the main sources for consumer financing and investment in the country. In 2011, loans issued by commercial banks reached up to 1.6 billion euros, or $34.3 \%$ of GDP.

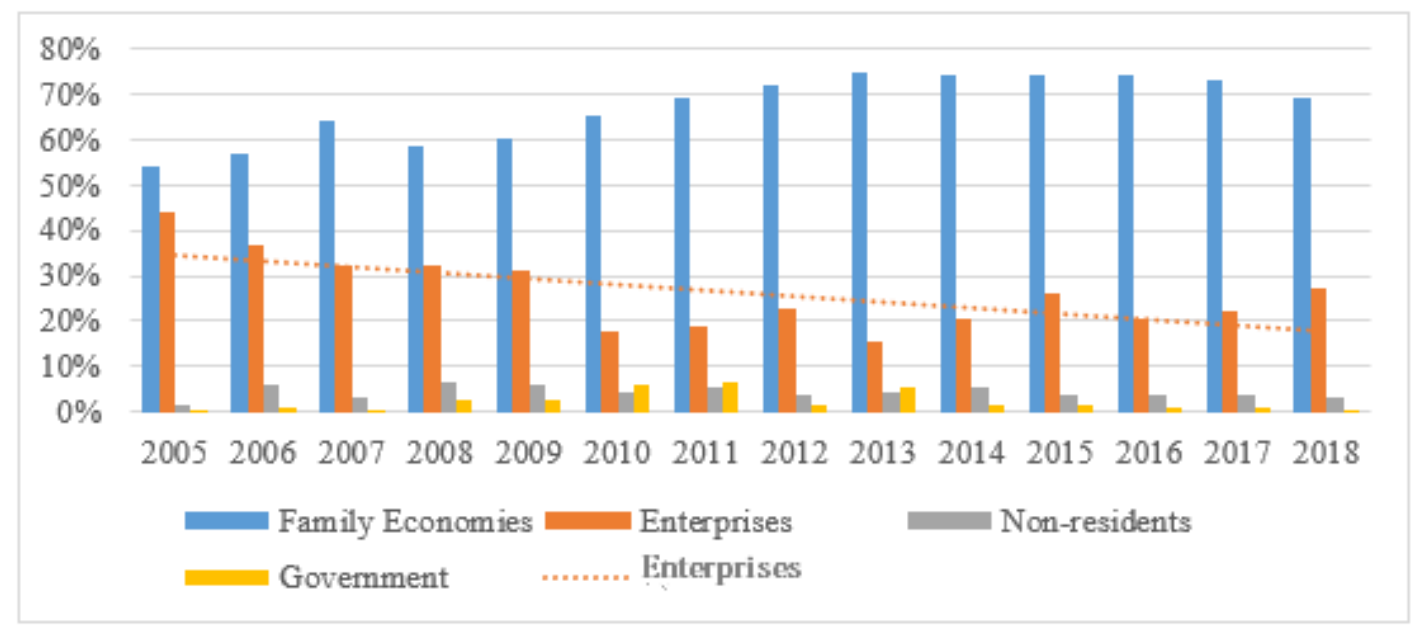

Figure 1. Graphic presentation of deposit structure in the banking sector in Kosovo (2005-2018)

Table 3. Percentage of loans in percentage in the banking system in Kosovo (2005-2018)

\begin{tabular}{ccc}
\hline Year & Enterprise Loans & Family Economies Loans \\
\hline 2005 & $74.20 \%$ & $25.80 \%$ \\
2006 & $76.80 \%$ & $23.20 \%$ \\
2007 & $77.40 \%$ & $22.60 \%$ \\
2008 & $76.80 \%$ & $23.20 \%$ \\
2009 & $75.70 \%$ & $24.30 \%$ \\
2010 & $70.90 \%$ & $29.10 \%$ \\
2011 & $69.00 \%$ & $29.70 \%$ \\
2012 & $67.00 \%$ & $30.70 \%$ \\
2013 & $67.70 \%$ & $30.80 \%$ \\
2014 & $67.30 \%$ & $31.40 \%$ \\
2015 & $66.70 \%$ & $33.00 \%$ \\
2016 & $64.80 \%$ & $35.00 \%$ \\
2017 & $64.00 \%$ & $35.80 \%$ \\
2018 & $63.58 \%$ & $36.42 \%$ \\
\hline
\end{tabular}




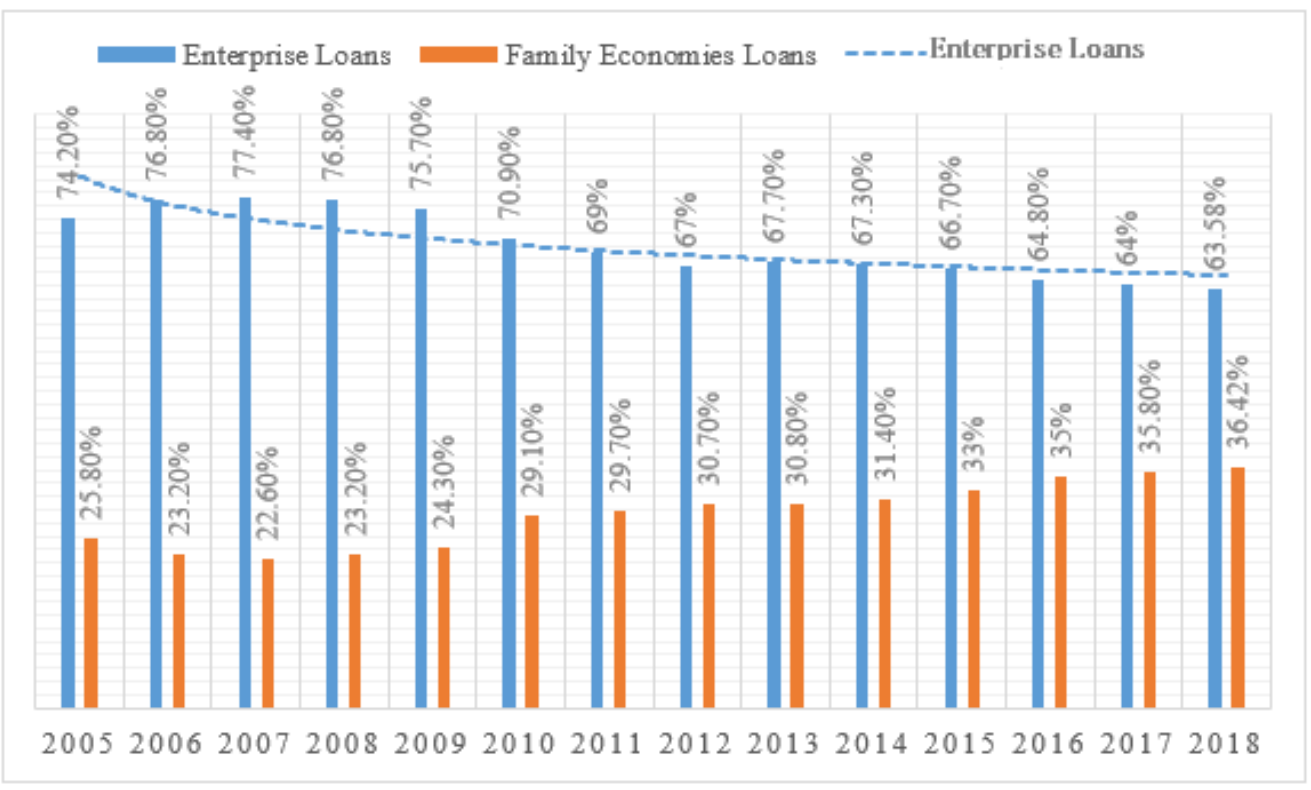

Figure 2. Percentage of loans in percentage in the banking system in Kosovo (2005-2018)

Loans issued to enterprises have increased annually by $13.5 \%$, while loans issued to households slowed the growth trend during 2011, marking an annual increase of $16.9 \%$ [45]. Despite the uncertainty in global financial markets, the perceptions of commercial banks in Kosovo about a more stable economic environment have contributed to further credit growth. The value of total loans issued by commercial banks in Kosovo in 2012 was 1.77 billion euros (36.2\% of GDP).

During this year, we have had a very small increase compared to last year and this mainly comes as a result of loans to enterprises (14.1\% in 2011 and 5.2\% in 2012). Based on the research reports of the Central Bank, during this year the banks have reported an increase in the demand for loans from SMEs and a decrease in the demand for loans from large enterprises. Commercial banks, despite the increase in the demand for loans from SMEs, continued to tighten the criteria and standards in the lending process [46].

In 2013 , the total amount of loans issued by commercial banks in Kosovo reached 1.83 billion euros. The annual growth of loans during this year was $2.8 \%$, which represents the lowest rate of credit growth since the beginning of the functioning of the banking system in Kosovo. During this year, commercial banks slowed down the lending process for enterprises and households, because the banking sector was characterized by a satisfactory level of liquidity and a good state of regulatory capital adequacy.

Credits for households have increased annually by $4.4 \%$, while loans to enterprises have had a smaller annual growth compared to the previous year (3.1\%) [47]. The year 2014 was characterized by recovery in the credit system in Kosovo. This year, the total value of loans reached 1.89 billion euros, which represents an annual increase in loans by $3.5 \%$. Even during this year we have credit facilitation for enterprises and households, due to liquidity and pressure from competition in the banking system in Kosovo.

SME loans during 2014 represented about $67.3 \%$ of total loans, while loans to households represented about $31.4 \%$ of the credit portfolio [48]. In 2015, loans remained the most important category of assets of the banking sector with a share of $61.3 \%$ in the total amount of assets of the banking sector. The total value of loans in 2015 was 2.01 billion euros, an annual increase of $6.1 \%$. The main reasons for this increase in lending activity, was the increase in the demand of businesses to expand their operating capacity and increase the level of consumption by Kosovar families [49].

Most of the loans in the banking sector in 2016 are dominated by loans to enterprises $(64.8 \%)$, while loans to households accounted for $35 \%$ of the loan portfolio. The total value of loans reached 2.17 billion euros, an annual increase of $8.4 \%$. During this year, it is noted that commercial banks have tightened lending criteria by applying higher interest rates, increasing collateral requirements and reducing the maturity of loans provided [50]. The year 2017 for the banking sector in Kosovo was characterized by the highest increase in lending activity in the last six years, an increase of $10 \%$.

Reducing interest rates and improving the quality of credit portfolios have contributed to the expansion of the lending activity. Also, the establishment of the Kosovo Credit Guarantee Fund, which provides collateral security for loans granted by commercial banks to SMEs, have positively impacted lending growth. Most of the loans in 2017 are dominated by loans to SMEs - $64 \%$, while loans to households represented $35.8 \%$ [51]. The average credit trend for real sector enterprises in Kosovo $(2005-2018)$ is $1,527.52$ or $€$ 1.52 billion, which shows that during this period we have had a continuous increase in the amount of loans in the real sector of the economy.

Interest rates on loans and deposits in Kosovo's banking sector have shown a steady downward trend. The gap between interest rates in recent years has narrowed, and this difference can be attributed to the steady decline in the concentration rate in the banking system. From this we can conclude that the competition in the banking system of Kosovo is increasing [52].

Between 2005 to 2009 the interest rates on loans were very high and reached the value of $15 \%$, while the interest rates on deposits were up to $4.5 \%$. Table 4 presents the interest rates on loans and deposits for the banking sector in Kosovo that include the time period analyzed in this study.

The average interest rate on loans has followed a stable trend, standing at $14.3 \%$ in 2010 . Enterprise loans from 2005 to 2010, had higher interest rates than loans to households. The main reasons for this are a more conservative approach of 
commercial banks to businesses and a higher probability of these businesses to fail in the undertaken projects, due to various upheavals that occur at the macroeconomic level [53]. In 2010, interest rates on deposits decreased when compared to the previous year. The average interest rate in 2010 was $4.0 \%$ and the decrease in interest rates may be a result of the decline in the lending process by the financial sector.

In 2010, interest rates on deposits decreased compared to the previous year. The average interest rate in 2010 was $4.0 \%$ and the decrease in interest rates may be a result of the decline in the lending process by the financial sector. During 2012, the average interest rate on loans decreased from $14.3 \%$ to $13.7 \%$, while the interest rate on deposits remained unchanged compared to the previous year. Factors that affect the interest rates in the banking system in Kosovo are: market conditions, operational efficiency, institutional factors and banking regulation. Also, the structure of the cost of financial intermediation has undergone changes during the period 2005 - 2011, as this is observed in the reduction of operating costs, thus exceeding the risk costs [46].

During 2013, interest rates on loans decreased from $13.7 \%$ to $12.8 \%$, while interest rates on deposits increased from $3.4 \%$ to $3.5 \%$. During this year, loans for investment purposes were characterized by lower interest rates compared to other business loans. The agricultural sector during 2013 also had a very high interest rate on loans $(18.4 \%)$, while interest rates on loans to the services sector reached the value of up to $12.8 \%$ [47].

Figure 3 shows graphically the interest rates on loans and deposits for the banking sector in Kosovo (2005 - 2018). The year 2014 in the banking sector in Kosovo was characterized by a significant decrease in interest rates on loans, but especially on deposits. The interest rate on loans decreased from $3.5 \%$ to $0.6 \%$. Such a sharp decline in interest rates on deposits was affected by the satisfactory supply of deposits. Compared to countries in the region, interest rates on loans in Kosovo in 2015 have declined more sharply, reaching an average close to the countries in the region. During this year, interest rates on loans decreased from $10.6 \%$ to $7.6 \%$, while interest rates on deposits increased from $0.6 \%$ to $0.8 \%$. If we compare this with the countries of the region, the interest rates on deposits are significantly lower in Kosovo [49].

During 2016, interest rates on loans to enterprises fell to $6.8 \%$ from $7.4 \%$. All categories of new loans to enterprises were characterized by declining interest rates. The average interest rate on investment loans decreased from $7.1 \%$ to $6.7 \%$, while the average interest rate on non-investment loans decreased from $8 \%$ to $6.8 \%$ [52]. The decline in banking interest rates was influenced by the decline in the average interest rate on both loans to enterprises and households. Interest rates on loans to enterprises in 2017 decreased to $6.6 \%$, while non-investment loans decreased to $6.3 \%$ [50].

The interest rate on loans in 2018 decreased by $0.81 \%$ compared to the previous year. This decline in interest rates on loans has come as a result of constant competitive pressures, improving the quality of credit portfolios, progress in structural reforms to reduce risks in the realization of collateral and good access to finance [51].

Table 4. Interest rates on loans and deposits in the banking system in Kosovo (2005-2018)

\begin{tabular}{lcccccc}
\hline Year & GDP (1.000Euro) & Interest rates on loans & Interest rates on deposits & Spread & CPI & Real Spread \\
\hline $\mathbf{2 0 0 5}$ & $3,002.900$ & $14.93 \%$ & $2.50 \%$ & $12.43 \%$ & $-1.40 \%$ & $14.03 \%$ \\
$\mathbf{2 0 0 6}$ & $3,120.400$ & $14.84 \%$ & $2.53 \%$ & $12.31 \%$ & $0.60 \%$ & $11.64 \%$ \\
$\mathbf{2 0 0 7}$ & $3,393.700$ & $14.68 \%$ & $3.11 \%$ & $11.57 \%$ & $4.30 \%$ & $6.97 \%$ \\
$\mathbf{2 0 0 8}$ & $3,290.837$ & $13.80 \%$ & $4.13 \%$ & $9.67 \%$ & $9.30 \%$ & $0.34 \%$ \\
$\mathbf{2 0 0 9}$ & $4,069.622$ & $14.40 \%$ & $4.21 \%$ & $10.19 \%$ & $-2.40 \%$ & $12.90 \%$ \\
$\mathbf{2 0 1 0}$ & $4,401.964$ & $14.30 \%$ & $4.00 \%$ & $10.30 \%$ & $3.50 \%$ & $6.57 \%$ \\
$\mathbf{2 0 1 1}$ & $4,814.535$ & $14.30 \%$ & $3.40 \%$ & $10.90 \%$ & $7.30 \%$ & $3.36 \%$ \\
$\mathbf{2 0 1 2}$ & $5,058.763$ & $13.70 \%$ & $3.40 \%$ & $10.30 \%$ & $2.50 \%$ & $7.61 \%$ \\
$\mathbf{2 0 1 3}$ & $5,326.617$ & $12.80 \%$ & $3.50 \%$ & $9.30 \%$ & $1.80 \%$ & $7.37 \%$ \\
$\mathbf{2 0 1 4}$ & $5,567.494$ & $10.60 \%$ & $0.60 \%$ & $10.00 \%$ & $0.40 \%$ & $9.56 \%$ \\
$\mathbf{2 0 1 5}$ & $5,807.009$ & $7.60 \%$ & $0.80 \%$ & $6.80 \%$ & $-0.50 \%$ & $7.34 \%$ \\
$\mathbf{2 0 1 6}$ & $6,070.113$ & $7.20 \%$ & $1.00 \%$ & $6.20 \%$ & $0.30 \%$ & $5.88 \%$ \\
$\mathbf{2 0 1 7}$ & $6,413.861$ & $6.80 \%$ & $1.10 \%$ & $5.70 \%$ & $1.50 \%$ & $4.14 \%$ \\
$\mathbf{2 0 1 8}$ & $6,725.913$ & $5.99 \%$ & $1.47 \%$ & $4.52 \%$ & $1.10 \%$ & $3.38 \%$ \\
\hline
\end{tabular}

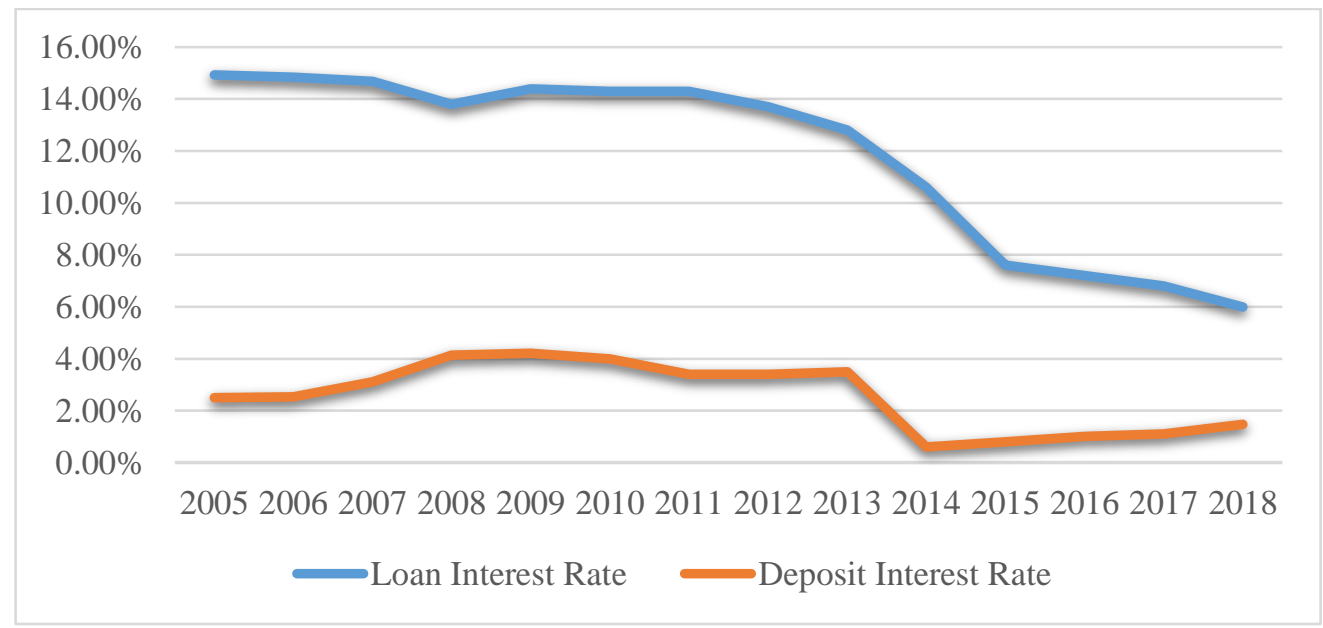

Figure 3. Graphical presentation of interest rates on loans and deposits in the banking sector in Kosovo (2005-2018) 
It is worth noting that the gap between the interest rate on loans and deposits has decreased and therefore we expect this economic effect to increase positively, due to the reduction of the real cost of capital during the analyzed period (2005-2018).

\section{METHODOLOGY AND SPECIFICATION OF ECONOMETRIC MODEL}

The research question of this study includes the issue of the impact of commercial banks on the development of the real sector of the economy, where through the lending process, the banking sector greatly affects the development and financial sustainability of businesses in a country.

During the interpretation of the empirical results, various comparisons will be made between the empirical findings of our study and the results from the studies of other authors.

\subsection{Motivation of the study}

We see different effects of these loans on economic development. While in some countries loans have positively affected GDP, in others they have had a negative effect. Because Kosovo is a newly founded state, we need to see if loans and banking systems contribute to the economic development.

Besides, as far as we investigated, there isn't any paper that analyzes the relationship between loans and GDP for Kosovo.

\subsection{Hypothesis of the study}

The hypothesis of this study is: Commercial banks through the lending process have had a substantial impact on the real sector of Kosovo's economy.

To test this hypothesis we applied quantitative methods, based on secondary data of annual financial reports to the Central Bank of Kosovo, the World Bank and the Agency for Statistics of Kosovo. To analyze the effects of bank loans on economic growth it is necessary to consider many other factors that explain the relationship between these variables. For the design and specification of the econometric model of this hypothesis, we have relied on several studies of other authors who have analyzed the impact of bank loans on economic growth.

It is worth noting that these studies are mainly divided into two categories in terms of their results and findings regarding the positive or negative impact of bank loans on economic growth. Many studies such as Petrescu and Pop, [24], Bezemer et al. [20], Ananzeh [43], Ermişoğlu et al. [37], Caporole et al. [19] have found positive links between bank loans and economic growth, while other authors Mian et al. [38], IbáñezHernández et al. [39], Mamman and Hashim [40], Leitão [42] have found negative impact of bank loans on economic growth and development of the real sector of the economy.

The econometric model constructed to test this hypothesis is based on the studies mentioned above, given that most of these authors used secondary data, including time series and dynamic models to test this hypothesis. We have also used data from the time series published by the Central Bank of Kosovo, the World Bank and the Kosovo Agency of Statistics for the period 2005 - 2018. The data included in these econometric models are data reported on a monthly basis, and the number of observations reaches up to 168 . The data are processed in the STATA program, and to confirm these hypotheses we have applied the following statistical tests: Linear Regression,
Fixed Effect and Random Effect, Hausman - Taylor Regression and Generalized Method of Moments (GMM).

Table 5 presents all the information and details about the variables included in the econometric models of this study.

Based on this study, we have constructed this econometric model which we will initially test through linear regression analysis:

$$
Y=\beta_{0}+\beta_{1} X_{1}+\beta_{2} X_{2}+\beta_{3} X_{3}+e
$$

where:

$\mathrm{Y}=$ Gross Domestic Product (GDP)

$\mathrm{X} 1=$ Bank Loans $(\mathrm{BL})$

$\mathrm{X} 2=$ Loan Interest Rate (LIR)

$\mathrm{X} 3=$ Consumer Price Index (CPI)

$\mathrm{e}=$ error term (stochastic variable)

Based on the data presented for the first econometric model, we have transformed each variable into logarithms through the function ( $\mathrm{Ln}$ ), in order to have an approximation of the values included in this econometric model. Then the form of the general equation appears in Table 5:

$$
L n G D P=\beta_{0}+\beta_{1} L n B L+\beta_{2} \operatorname{Ln} L I R+\beta_{3} L n C P I+e
$$

The main purpose of using these models lies in the fact that we are dealing with panel data and dynamic models. Through these statistical tests most authors have identified the link between bank loans and economic growth. Table 5 presents the variables that will be used to construct the econometric model and test the hypothesis of this study.

In this econometric model, the dependent variable will be GDP as one of the most important indicators of economic growth. The values of this variable are taken from the annual reports published by the Kosovo Agency of Statistics and the World Bank. GDP values are taken in monetary amounts, expressed in euros and are presented on a monthly basis. The first independent variable included in this econometric model is the amount of bank loans. This variable is estimated to be the main independent variable of this model, because it mostly explains the economic growth of the real sector of the economy.

The loans that have been considered in this econometric model are only loans granted by commercial banks to the business sector in Kosovo. The values of this variable are taken from the financial stability reports published by the Central Bank of Kosovo and the annual financial reports of the Association of Kosovo Banks. To analyze the impact of bank loans on economic growth, numerous scientific studies have also looked at the norms of interest on credit and inflation rates as other very important indicators that directly affect lending to the real sector of the economy and the GDP of a country.

The interest rate on credit, which is estimated to be the cost of obtaining a bank loan from borrowers, is a very important factor in commercial bank loans and economic growth. Various macroeconomic theories explain the impact of interest rates on economic growth, but also on loans to the banking sector. The behavior of interest rates largely depends on the inflation rate. Therefore, in this econometric model, as the third independent variable, we have obtained the inflation rate for the period $2005-2018$. For this variable, the data are taken from the quarterly ratios of the consumer price index, published by the Kosovo Agency of Statistics. 
Table 5. Description of the variables included in the econometric model

\begin{tabular}{|c|c|c|}
\hline Variable & Description of variables & Data source \\
\hline $\begin{array}{l}\text { Dependent } \\
\text { variable }\end{array}$ & Gross Domestic Product (GDP) & $\begin{array}{c}\text { Annual reports of the Kosovo Agency of Statistics (2005-2018) and the annual } \\
\text { financial reports of the World Bank }\end{array}$ \\
\hline $\begin{array}{l}\text { Independent } \\
\text { variable }\end{array}$ & Bank Loans (BL) & $\begin{array}{c}\text { Financial Stability Reports } 2005 \text { - } 2018 \text { (Central Bank of Kosovo) and annual reports } \\
\text { of the Kosovo Banking Association }\end{array}$ \\
\hline $\begin{array}{l}\text { Independent } \\
\text { variable }\end{array}$ & Loan Interest Rate (LIR) & $\begin{array}{c}\text { Financial Stability Reports } 2005 \text { - } 2018 \text { (Central Bank of Kosovo) and annual reports } \\
\text { of the Kosovo Banking Association }\end{array}$ \\
\hline $\begin{array}{l}\text { Independent } \\
\text { variable }\end{array}$ & Consumer Price Index (CPI) & $\begin{array}{c}\text { Annual reports of the Kosovo Agency of Statistics (2005-2018) and the annual } \\
\text { financial reports of the World Bank }\end{array}$ \\
\hline
\end{tabular}

\section{DESCRIPTIVE STATISTICS AND CORRELATION ANALYSIS}

Through descriptive statistics we will describe some of the statistical data for the variables which are included in the first econometric model and will analyze the Pearson correlation coefficient between the dependent variable and the independent variables which are included in this study. Initially, we will be analyzing the mean, standard deviation, maximum and minimum values, variance, kurtosis and curve.

The following table presents the descriptive statistics for the variables included in the first econometric model as well as the normal distribution of these variables through the histogram. The main purpose of using these descriptive analyzes is to identify the accuracy of the data, which are taken into account in the measurement of econometric models. According to the data presented in the Table 6 below, it can be noticed that the minimum values of GDP on a monthly basis amount to 504.4 million $€$ at the beginning of 2005 and 1.96 billion $€$ at the end of 2018 .

The average value of GDP during this period (2005-2018) is $€ 1.2$ billion with a standard deviation of 354.84 . Commercial bank loans at the beginning of 2005 amounted to $€ 381.8$ million, while at the end of 2018 the value of business loans in Kosovo reached $€ 2.75$ billion. Based on these values, we can see a positive trend of growth of bank loans in Kosovo during the period 2005 - 2018, where the average value of these loans reached $€ 1.54$ billion with a standard deviation of 640.54 . The lowest value of the interest rate on credit was $6 \%$, while the highest value during this time period was $16.2 \%$. The average interest rate is $11.84 \%$ with a standard deviation of 3.17.

The last variable included in this econometric model is the consumer price index, an index which until 2015 was measured with the base year 2002, while from 2016 onwards, the base year which serves to measure the harmonized index price is 2015. The minimum value of this index at the beginning of 2015 had a specificity of 76.1 and a maximum value of this index of 104.80. The average of this index reaches the value of 92.85 with a standard deviation of 9.10 .

According to the graphical representation (Figure 4) it can be done that the dependent variable (GDP) has a normal distribution of values, causing the curve to be approximately symmetrical which means that the values included in this econometric model are fully measurable. Based on the same principle, the main independent variable (bank loans) has a normal distribution, which means a greater accuracy in data collection and measurement. Both variables presented through the histogram have a mesokurtic curve with an absolute value of 3 .

Figure 5 graphically shows the normal distribution of interest rates on loans and the consumer price index.

Table 6. Descriptive statistics for variables included in the econometric model

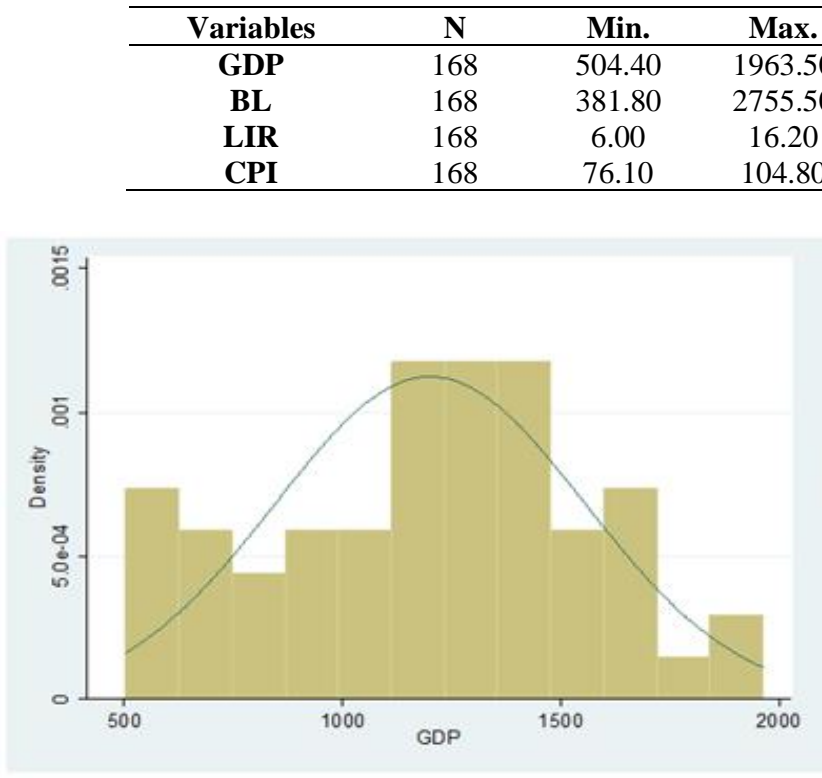

(a) GDP

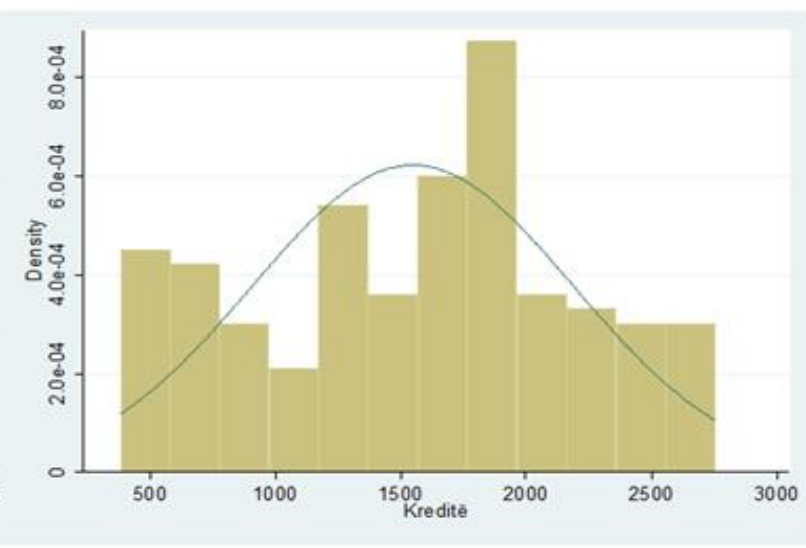

(b) Bank Loans

Figure 4. Graphical representation of normal distribution of GDP and bank loans through histogram 
In the continuation of this study, we will analyze the correlation between the variables included in this econometric model. Correlation measurement will be done through the Pearson coefficient, which shows the interrelationship between the independent variables with the dependent variable. Table 7 shows the values of the correlation coefficient between GDP and other independent variables.

According to the data presented in the table above, one can notice that all the variables incorporated in this model are correlated with each other. We will first analyze the correlation between GDP and other independent variables. The gross domestic product has a positive correlation with loans and the consumer price index, while a negative correlation with interest rates on loans. The positive correlation between GDP and bank loans is 0.868, which means a strong link between these variables, where with the increase in loans we will have an increase in gross domestic product and vice versa.

This relationship between the two variables is also at the level of statistical significance P-value $=0.000$, which means a value less than 0.05 . To confirm the validity of the hypothesis, if commercial bank loans have affected the economic growth of the real sector, we have used various statistical tests and trend analysis, which will confirm the accuracy of the above statements.

The correlation between GDP and interest rates on loans is negative (-0.819), which means that an increase in interest rates on loans has caused a decline in GDP and vice versa. Given that since 2005 we have had very high interest rates on loans, this has caused very high costs for potential borrowers to get a loan, affecting the increase in credit risk and the decline in lending.

The Pearson coefficient value between the interest rate on credit and GDP is a strong significant link, proving a very important empirical relationship between these two variables. Figure 6 graphically shows, in the first part the positive correlation between GDP and bank loans and in the second part of the graph, the negative correlation between GDP and interest rates on loans.

GDP and consumer price index according to the results of the correlation analysis presented in Table 7 , have a positive correlation between them. The value of the Pearson coefficient, in this case is 0.800 , which shows that the increase in the inflation rate causes an increase in GDP in Kosovo. Such a correlation value indicates a strong link between these two variables, given the very large impact of inflation on a country's economic growth.

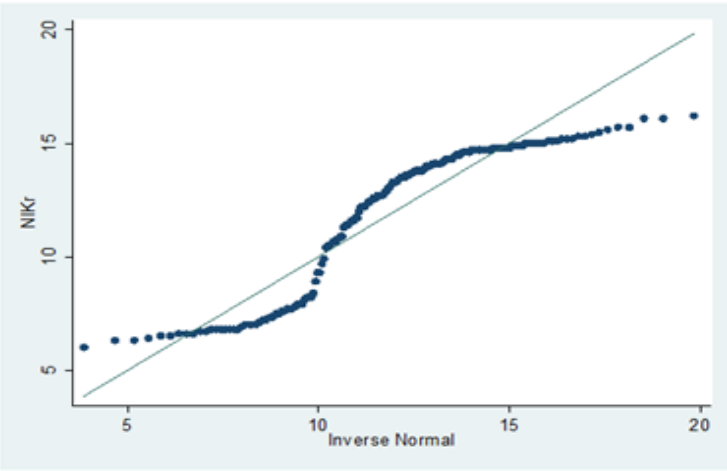

(a) Loan Interest Rate

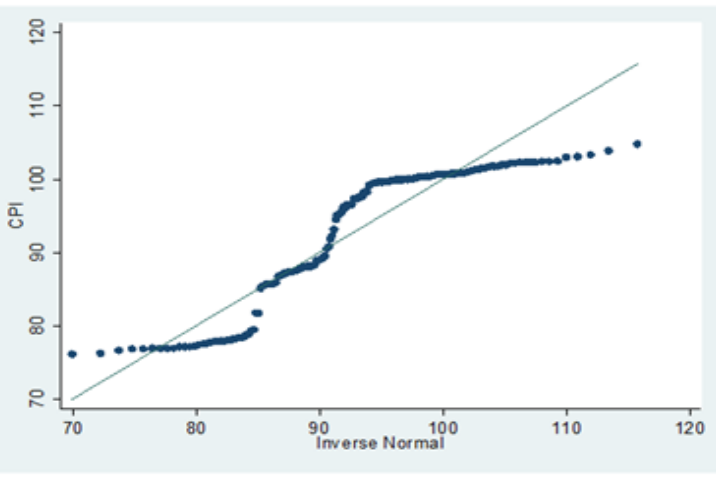

(b) Consumer Price Index

Figure 5. Graphical representation of the normal distribution of interest rates on credit and CPI

Table 7. Pearson correlation analysis for the variables included in the econometric model

\begin{tabular}{ccccc}
\hline Variables & GDP & BL & LIR & CPI \\
\hline GDP & 1 & 0.868 & -0.819 & 0.800 \\
BL & 0.868 & 1 & -0.886 & 0.947 \\
LIR & -0.819 & -0.886 & 1 & -0.788 \\
CPI & 0.800 & 0.947 & -0.788 & 1 \\
\hline
\end{tabular}

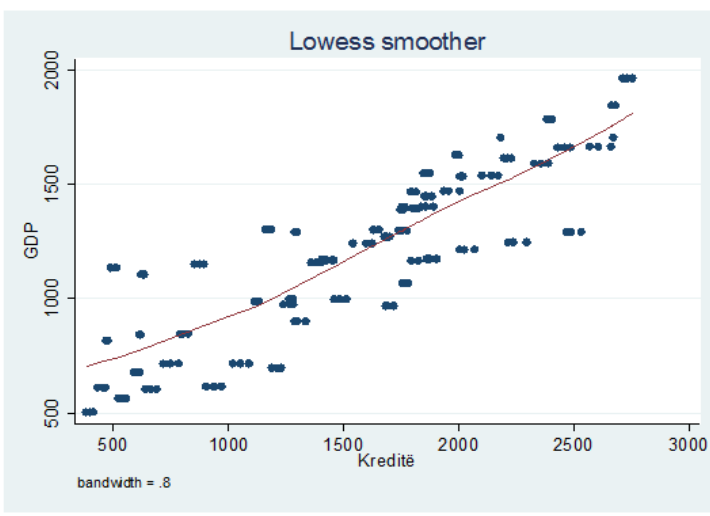

(a) GDP - Bank Loans

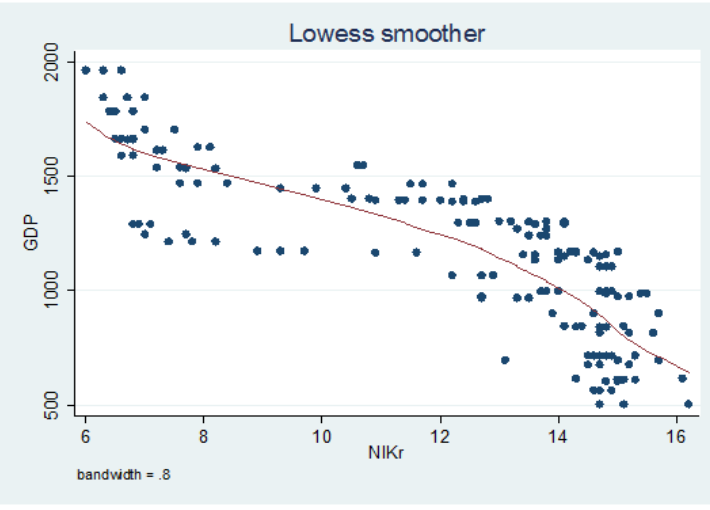

(b) GDP - Interest Rate

Figure 6. Graphical presentation of Pearson correlation between GDP with bank loans and interest rates on loans 


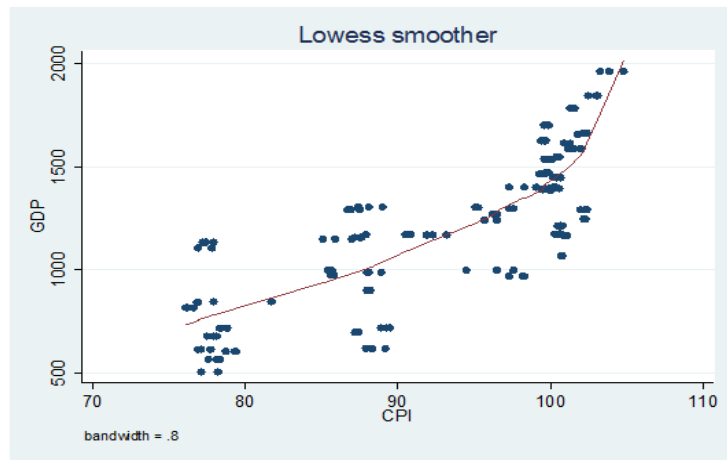

(a) GDP - CPI

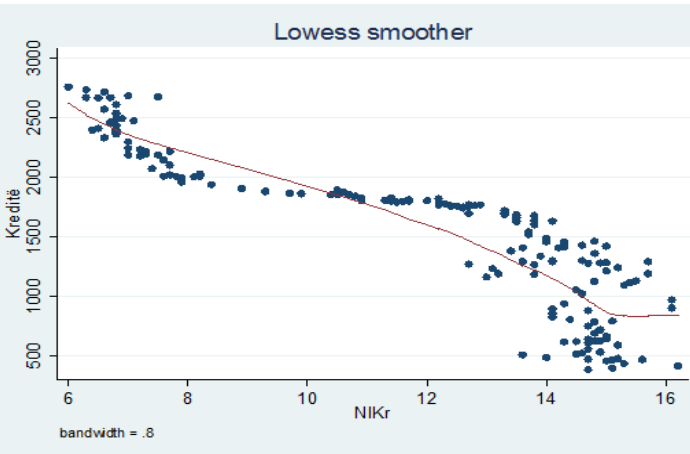

(b) GDP - Interest Rate

Figure 7. Graphical presentation of Pearson correlation between GDP with CPI and the correlation between loans and interest rates on loans

Such a correlation value indicates a strong link between these two variables, given the very large impact of inflation on a country's economic growth. Pearson's correlation between bank loans and interest rates shows a negative correlation, which means that as interest rates rise, commercial banks' loans to the real sector of the economy will decline, and vice versa.

In Figure 7, we present in the first part of the graph the relationship between GDP with the consumer price index, and in the second part the relationship between bank loans and interest rates on loans.

The Pearson coefficient value between bank loans and interest rates is -0.886 , expressing a strong negative correlation between these two variables. If we analyze the correlation between interest rates and the consumer price index, we can see that we have a high negative relationship in the value of -0.788 . This means that an increase in the inflation rate has caused a decrease in the interest rate on credit, an increase in lending and an increase in GDP.

\section{MULTIFACTORIAL REGRESSION ANALYSIS}

To confirm the hypothesis of this study, we will apply some statistical tests through the Stata application software, and we will present in a special way the results of each econometric model, performing comparative analysis between the results and the findings of the study. To analyze the impact of bank loans on economic growth, we have relied on several studies by other authors such as Bezemer [20], Cojocaru, Hoffman and Miller [21], Demirgüç-Kunt and Levine [22], Huang and Wang [23], Petrescu and Pop [24], etc.

Most of these authors have used data from dynamic panels, building different econometric models to analyze the impact of bank loans on economic growth. For the specification of the econometric model, we have relied mainly on these studies, but as a reference for the construction of this econometric model for the first hypothesis, we have taken the study of Romanian authors Petrescu and Pop [24], who analyzed the effects of credit activity of commercial banks in Romanian economic growth [22].

This study was conducted in 2015 and covers the period between 1990 to 2014. The authors used GDP as a dependent variable, and their independent variables consisted of the amount of bank loans, interest rate on credit and consumer price index, as an important measure of inflation. The results of this study showed a positive impact of loans on economic growth as well as a negative impact of interest rates and inflation on economic growth. All the values included in the variables of this study, the authors have turned into logarithmic models, enabling a normal distribution between variables and more accurate empirical results.

Table 8 presents the econometric results of the standard multiple regression analysis.

Based on the Table 8, the general form of the linear regression equation takes this form:

$$
\begin{gathered}
\text { Ln } G D P=6.063012+0.50279 B L-0.26797 L I R- \\
0.443537 C P I+0.2673
\end{gathered}
$$

Based on the values presented in the table we can see that bank loans and interest rates are at the standard level of significance. While the third independent variable, based on regression analysis is not significant, because the p-value is above the standard level (0.353). Therefore, based on this statement, we will not interpret the impact of inflation on economic growth, because this model, through regression analysis, turns out to have multicollinearity.

Table 8. Results of multifactorial linear regression analysis

\begin{tabular}{ccccccc}
\hline Ln GDP & Coef. & Std. Error & $\mathbf{t}$ & $\mathbf{P}>|\mathbf{t}|$ & $\mathbf{9 5 \%}$ Conf. Interval & 95\% Conf. Interval \\
\hline Ln BL & 0.502793 & 0.0977073 & 5.15 & 0.000 & 0.3098664 & 0.6957195 \\
Ln LIR & -0.267978 & 0.0670369 & -4.00 & 0.000 & -0.4003446 & -0.1356113 \\
Ln CPI & -0.4435357 & 0.4761586 & -0.93 & 0.353 & -1.383727 & 0.4966558 \\
cons. & 6.063012 & 1.575241 & 3.85 & 0.000 & 2.952645 & 9.173379 \\
\hline
\end{tabular}

Table 9. Results of multifactorial linear regression analysis after CPI removal

\begin{tabular}{ccccccc}
\hline Ln GDP & Coef. & Std. Error & $\mathbf{t}$ & $\mathbf{P}>|\mathbf{t}|$ & $\mathbf{9 5 \%}$ Conf. Interval & 95\% Conf. Interval \\
\hline Ln BL & 0.4196456 & 0.0397186 & 10.57 & 0.000 & 0.3412233 & 0.4980678 \\
Ln LIR & -0.2650849 & 0.066938 & -3.96 & 0.000 & -0.3972504 & -0.1329194 \\
cons. & 4.649969 & 0.4242947 & 10.96 & 0.000 & 3.812222 & 5.487716 \\
\hline
\end{tabular}


Therefore, by comparing the $\mathrm{T}$ test and the $\mathrm{F}$ test, we will see if the previous model or the following model are more accurate. Multicollinearity will be identified if there is a current relationship between the independent variables. To know which model is more accurate, then the values of the $T$ test and the $\mathrm{F}$ test must be greater than the values of the previous model. So, if we remove the consumer price index from the model, then the econometric results are as in the following Table 9.

So, if we remove the consumer price index from the model, then the econometric results are as in Table 9.

By comparing the results of the first model with the second model, we conclude that the second model is more accurate because the value of the T test for the variable (bank loans) is greater in the second model (10.57) than in the first model (5.15). Also, for the second variable (interest rate on credit), the value of the $\mathrm{T}$ test is greater in the second model. Another statistical argument, which proves that the results of the second model through linear regression analysis, is also the result of the $\mathrm{F}$ test, which in the second model has a higher value 224.48 , than in the first model where its value was 149.83 .

The coefficient of determination ( $\mathrm{R}$ Square) in this case is $73.13 \%$, indicating a high relationship between the dependent and independent variables. This coefficient shows that for the value of $73.13 \%$, loans and interest rates on loans explain the economic growth of Kosovo for the period 2005 - 2018. If other factors remain constant, (bank loans and interest rates on loans are zero), then the value of GDP will be $€ 4.64$ billion. But if we assume that we have an increase of $1 \%$ in bank loans, keeping interest rates constant, then this will affect the growth of GDP by $0.41 \%$. This statement is correct because the bank loan variable is at the standard level of significance $(\mathrm{P}$-value $=$ $0.000<0.005)$.

However, the question arises as to what is the impact of interest rates on GDP. The main reason why the interest rate on loans and the consumer price index were taken int o consideration, is because these two are very important indicators that affect the amount of loans provided by commercial banks to the real sector of the economy. If we have an increase in the interest rate by $1 \%$, keeping bank loans constant, this will affect the reduction of GDP by $0.26 \%$. This statement is also true at the $95 \%$ confidence level $(\mathrm{p}$-value $=$ $0.000<0.05$ )

It is worth noting that according to regression analysis, the biggest effects on economic growth are bank loans, because in recent years in Kosovo, the reduction of interest rates on loans, has caused an increase in the volume of loans. According to economic theory, an increase in the level of loans causes an increase in consumption, and given that one of the most important components that contributes to GDP growth is consumption, then consequently the impact of loans on economic growth in the case of Kosovo is very big. Since the value of the Pearson coefficient between bank loans and interest rates was negative $(-0.886)$, as a result we can conclude that the decrease in interest rates on loans, in recent years has caused an increase in the volume of loans of commercial banks for the business sector, and an increase in credit also has effects on economic growth.

\section{RANDOM EFFECTS GLS REGRESSION}

The specification of the dynamic panel model (Random Effects) to test the impact of bank loans on the economic growth of the real sector is as follows:

$$
L n G D P_{i t}=\beta_{0}+\beta_{1} L n B L_{i t}+\beta_{2} L n L I R_{i t}+\beta_{3} L n C P I_{i t}+\gamma_{i t}
$$

All the symbols presented in the above econometric model are the same as in the analysis of multiple linear regression, except for the symbol $\mathrm{i}$, which represents the code through which the data coding is done on a monthly basis divided into 12 groups, and the symbol t, representing the period 2005 2018. Table 10 will present the results of the regression analysis using the random effect.

Based on the values presented in the random effect results, the equation of the econometric model takes this form

$$
\begin{gathered}
\text { Ln GDP } P_{i t}=2.921342+0.3001479 B L_{i t}-0.2181946 \\
L I R_{i t}+0.5477377 C P I_{i t}+0.12
\end{gathered}
$$

According to the results in Table 10, we can see that all variables are found within the interval of reliability $90-95 \%$. The value of the determination coefficient is $88 \%$, which means that for this value, the independent variables explain the dependent variable (GDP)

Assuming that other factors affecting economic growth are constant, then the value of GDP will be $€ 2.92$ billion. If we have a $1 \%$ increase in bank loans while maintaining constant interest rates on loans and the consumer price index, this will increase GDP by $0.3 \%$, given that this is acceptable once it is found within the $95 \%$ reliability interval.

The effects of interest rates on gross domestic product are the same as in linear regression analysis. If interest rates on loans increased by $1 \%$, keeping bank loans and inflation constant, this reduces GDP by $0.21 \%$. Whereas, in the case where we have an increase of the consumer price index by $1 \%$, this affects the increase of the value of GDP by $0.54 \%$.

In terms of the effects of inflation on economic growth, based on this analysis it is significant in the $90 \%$ confidence interval. These results of this model provide greater support, confirming the hypothesis of this study.

\section{FIXED EFFECTS REGRESSION}

One of the most important tests that has a very wide application in statistics for dynamic panel data is the fixed effect model. The main purpose of using this model is because the data are not random and in this analysis the evaluator of fixed effects is used referring to the internal evaluator of regression coefficients. Table 11 shows the results of the econometric model through fixed effects.

Table 10. Results of the Random - Effect (GLS Regression)

\begin{tabular}{ccccccc}
\hline Ln GDP & Coef. & Std. Error & $\mathbf{Z}$ & $\mathbf{P}>|\mathbf{z}|$ & 95\% Conf. Interval & 95\% Conf. Interval \\
\hline Ln BL & 0.3001479 & 0.0610497 & 4.92 & 0.000 & 0.1804927 & 0.4198031 \\
Ln LIR & -0.2181946 & 0.0403106 & -5.41 & 0.000 & -0.2972018 & -0.1391873 \\
Ln CPI & 0.5477377 & 0.2974864 & 1.84 & 0.066 & -0.035325 & 1.1308 \\
cons. & 2.921342 & 0.9785605 & 2.99 & 0.003 & 1.003398 & 4.839285 \\
\hline
\end{tabular}


Table 11. Results of fixed - effect regression

\begin{tabular}{ccccccc}
\hline Ln GDP & Coef. & Std. Error & $\mathbf{z}$ & $\mathbf{P}>|\mathbf{z}|$ & 95\% Conf. Interval & 95\% Conf. Interval \\
\hline Ln BL & 0.2844542 & 0.0594557 & 4.78 & 0.000 & 0.1669818 & 0.4019266 \\
Ln LIR & -0.2145418 & 0.0391479 & -5.48 & 0.000 & -0.2918901 & -0.13781936 \\
Ln CPI & 0.6244526 & 0.2897169 & 2.16 & 0.033 & 0.0520303 & 1.196875 \\
cons. & 2.678772 & 0.9521403 & 2.81 & 0.006 & 0.7975342 & 4.56001 \\
\hline
\end{tabular}

The results presented in the table above are approximately the same results as the results of random effect models. All independent variables are significant at the 95\% confidence level and all other parameters are statistically measurable. The value of parameter $b_{0}$ is at the standard level of significance $(p$-value $=0.000<0.05)$ which means that if other factors are constant, the value of GDP will be $€ 2.67$ billion.

The results of this model are in favor of interpreting the hypothesis of this study, resulting in a positive relationship between bank loans and economic growth in Kosovo. If lending to businesses increases by $1 \%$ while keeping interest rates and inflation constant, this will increase the value of GDP by $0.28 \%$. The standard error value for parameter $b_{1}$ is 0.0594 , which means that this parameter has a very small value of the standard error and this comes as a result of the positive correlation with the GDP values. Variation of the parameter variable $b_{1}=0.0594^{2}=0.0035$ and this parameter has statistical significance because the actual value of the $T$ test $\left(t_{f}\right.$ $=4.78)$ is a value greater than the critical value of the $\mathrm{T}$ test $\left(t_{k r}=1.984\right)$.

The interest rate on loans negatively affects economic growth, where a $1 \%$ increase in the interest rate causes a decrease in GDP by $0.21 \%$. Such an effect is caused because in the period between 2005 and 2011 we had very high interest rates on loans, which have caused very high financing costs for borrowers. According to the results of the fixed effects method, the parameter $b_{2}$ is at the standard significance level (p-value $=0.000<0.05)$ and has a standard error of 0.0391 . This small standard error value means that the points on the regression line are very close to the straight line and we have a normal distribution between the values of $\mathrm{X}_{2}$ and $\mathrm{Y}$. Variation of the parameter variable $b_{2}=0.0391^{2}=0.00152$.

The results of regression through the method of fixed effects turn out to be very important in the relationship between the consumer price index and gross domestic product in Kosovo for the period 2005 - 2018. If we have an increase in inflation by $1 \%$ keeping constant loans and interest rate, then it follows that GDP will increase by $0.62 \%$. It is worth noting that in the context of independent variables, the biggest impact on economic growth has to be the consumer price index, because inflation has a positive relationship with commercial bank loans, whereby with increasing inflation rates, lending increases and consumption increases leading to the largest contributors to Kosovo's economic growth.

The standard error value for the consumer price index is 0.2897 , which is a value greater than the standard error of other parameters included in this econometric model. The variation of the estimator for the parameter $b_{3}=0.2897^{2}=0.0839$ and this parameter has statistical significance because the actual value of the $T$ test $\left(t_{f}=2.16\right)$ is a value greater than the critical value of this model $\left(\mathrm{t}_{\mathrm{kr}}=1.984\right)$.

Another very important test to prove the alternative hypothesis is the F test. The actual value of this test is 369.48 , while its critical value is 2.60 and by comparing these two values, we can conclude that the basic hypothesis in this case is not accepted, but the alternative hypothesis, that banks through the lending process have had a positive impact, is valid in the development of the real sector of the economy.

\section{HAUSMAN - TAYLOR REGRESSION}

The Hausman and Taylor model (1981) is a hybrid statistical model that combines the consistency of a fixed effect model with the efficiency and applicability of a random effect model. The data of this study will be tested through this model, in order to make comparisons with other statistical tests. Hausman - Taylor Regression takes into account the effect of exogenous variables on observations included in the econometric model. Two very important variables that explain the impact of bank loans on economic growth are interest rates on loans and the consumer price index. The following table shows the econometric results of regression analysis using the Hausman-Taylor model (See in Table 12).

According to the data presented in the table above, we can see that all the variables included in this econometric model are statistically significant at the $95 \%$ reliability level. The coefficient of the parameter $b_{0}=2.608$ is significant and this coefficient is taking into account that if the other factors are constant, then the value of GDP will be $€ 2.6$ billion. The main independent variable, bank loans, has a positive impact on economic growth, so if we have an increase in bank loans to businesses by $1 \%$ while maintaining constant interest rates and inflation, GDP will increase by $0.29 \%$. This statement is correct because if we take into account the actual value of the $\mathrm{T}$ test $\left(\mathrm{t}_{\mathrm{f}}=4.90\right)$, it is a value greater than the critical value $\left(\mathrm{t}_{\mathrm{kr}}\right.$ $=1.984$ ) and this fact highlights the positive impact of bank loans on economic growth. The value of the standard error for this parameter is 0.0596 and the variation of the estimator of this parameter is $b_{1}=0.0596^{2}=0.00355$.

The results of the Hausman-Taylor Regression model on the impact of interest rates on loans and inflation on economic growth are the same as previous models. When interest rates on loans increased by $1 \%$ while maintaining constant bank loans and the consumer price index, the effect will be the reduction of GDP by $0.21 \%$. Standard error for parameter $b_{2}=$ 0.0392, a value which indicates that the points on the regression line are very close to the line and this value indicates normal distribution between the values of $\mathrm{X}_{2}$ and $\mathrm{Y}$. Variance of parameter estimator $b_{2}=0.0392^{2}=0.00153$ and value the actual T-test is -5.52 .

The consumer price index has a positive effect on economic growth, a result which is consistent with other estimates of econometric models. Assuming a 1\% increase in this index, it affects GDP growth by $0.57 \%$. The standard error value for parameter $b_{3}=0.2901$, while the variable of the estimator for parameter $b_{3}=0.2901^{2}=0.0841$. The actual value of the T test for this parameter is 1.98 , which is approximately the same as the critical value of the $\mathrm{T}$ test (1.984), therefore the significance level for this variable is very close to the standard level of $5 \%$. 
Table 12. Results of hausman - taylor regression

\begin{tabular}{ccccccc}
\hline Ln GDP & Coef. & Std. Error & $\mathbf{z}$ & $\mathbf{P}>|\mathbf{z}|$ & $\mathbf{9 5 \%}$ Conf. Interval & 95\% Conf. Interval \\
\hline Ln BL & 0.2920682 & 0.0596469 & 4.90 & 0.000 & 0.1751625 & 0.4089739 \\
Ln LIR & -0.2165799 & 0.0392393 & -5.52 & 0.000 & 0.0050024 & -0.1396723 \\
Ln CPI & 0.5737179 & 0.2901663 & 1.98 & 0.048 & 0.0050024 & 1.142433 \\
cons. & 2.608397 & 0.9558181 & 2.73 & 0.006 & 0.7350275 & 4.481766 \\
\hline
\end{tabular}

Table 13. Results of GMM model - arellano bond estimation

\begin{tabular}{ccccccc}
\hline Ln GDP & Coef. & Std. Error & $\mathbf{z}$ & $\mathbf{P}>|\mathbf{z}|$ & $\mathbf{9 5 \%}$ Conf. Interval & 95\% Conf. Interval \\
\hline Ln BL & 0.3292271 & 0.0511212 & 6.44 & 0.000 & 0.2290315 & 0.4294228 \\
Ln LIR & -0.1842082 & 0.028681 & -6.42 & 0.000 & -0.2404219 & -0.1279946 \\
Ln CPI & 0.5839103 & 0.2140887 & 2.73 & 0.006 & 0.1643041 & 1.003516 \\
cons. & 2.464717 & 0.6575868 & 3.75 & 0.000 & 1.176459 & 3.752975 \\
\hline
\end{tabular}

\section{GENERALIZED METHOD OF MOMENTS (GMM) - ARELLANO BOND ESTIMATION}

In statistics and econometrics, the GMM model is one of the general methods applied for evaluating parameters in statistical models. This model is usually applied to dynamic panel data and has a number of samples over 100. Another important criterion for the implementation of this model is the value of the parameters included in other models must be very close to zero and through this method one also explains the problem of variable endogeneity.

Based on these assumptions, our model meets almost all the prerequisites required for the implementation of this model during the testing of the hypothesis of this study. The sample included in our model is 168 , the data are coded according to time series and dynamic panel and there is the problem of endogeneity between the independent variable (bank loans) and the dependent variable (GDP).

Many studies by other authors in this field have shown that in different countries, loans have a positive but also a negative effect on economic growth. Therefore, in the case of Kosovo, to solve this problem we will apply the GMM model, through the Arellano Bond Estimation method which gives concrete results, and removing the dilemma that exists regarding the effects of bank loans on the economic growth of the real sector. The following table shows all the econometric results of the GMM model, using the Arellano Bond Estimation method (See in Table 13).

All the results presented through these econometric models give greater stability to the econometric model constructed to test the hypothesis of this study. From the results of the GMM model, all independent variables are at the standard level of significance $95 \%$, which means that based on these statistical parameters, the main hypothesis of this study is accepted, and we conclude that commercial banks, through the lending process, have achieved substantial impact (positive) in the real sector of Kosovo's economy.

The parameter $b_{0}=2.4647$, is significant at the level of $95 \%$ and if other constant factors are maintained, then the value of GDP will be $€ 2.46$ billion. The standard error value for this parameter is 0.6572 and the actual value of the $T$ test is a value greater than the critical value $(3.73>1.984)$. The results of this model also explain the problem of endogeneity between bank loans and GDP, noting that loans have a positive impact on economic growth.

An increase of $1 \%$ in loans causes an increase in the value of GDP of $0.32 \%$. This value is greater than in other statistical tests and this gives us further empirical evidence for the positive impact of loans on Kosovo's economic growth in the period 2005 - 2018. Standard error for parameter $b_{1}=0.0511$, which if compared to the previous models is very similar. The variation of the estimator of this parameter is $b_{1}=0.0511^{2}=$ 0.0026 and the actual value of the $\mathrm{T}$ test $(6.44)$ is a value greater than the critical one (1.984).

The two main independent variables that affect the endogenous variable (bank loans) and the dependent variable (GDP) are important at the standard level of significance, giving greater empirical support to the findings of this study. So, even from the results of the GMM model, the increase in the interest rate causes a decrease in the value of GDP and the increase of the consumer price index leads to the increase of the value of GDP. The standard errors of these two parameters are very small and also the actual values of the $T$ test are greater than the critical values.

\section{CONCLUSIONS AND RECOMMENDATIONS}

The economic impact that commercial banks have on a country's economic development is very important for maintaining the current economic level and for development in the future. Banks and other financial institutions are the transformers of investment savings and for return to savings. Payments and consumption are mainly directed through banks, including exports, imports and government spending, a fact that requires a functioning and sustainable financial system. Banks as financial intermediaries have advanced and specialized knowledge to invest in areas that offer higher returns and this plays a role in attracting larger deposits in perspective. The amount of loans in 2018 in the banking sector in Kosovo had reached the value of $€ 2.75$ billion, while deposits were recorded at $€ 3.22$ billion.

The results show that commercial banks, through the lending process, have had a positive impact on the development of the real sector in the economy of Kosovo. The main conclusions that emerge from this study are:

Based on descriptive statistics, it turns out that all variables included in the model have normal distributions and show that the values of these variables are quite accurate and have influenced the increase of statistical reliability of the econometric model.

According to the results of the correlation analysis, it is noticed that we have a positive linear relationship between GDP and bank loans (0.868), which means that the increase in the volume of loans to businesses has caused an increase in GDP. 
Based on this analysis, it turns out that we have a negative linear relationship between the interest rate on credit and GDP (- 0.819), where the increase in interest rates on credit will cause a decrease in GDP and vice versa.

This study found that between the consumer price index and the gross domestic product there is a high positive linear relationship (0.800), where the increase in inflation has caused the growth of GDP in Kosovo for the period $2005-2018$.

Based on the empirical results through econometric models it can be concluded that bank loans and consumer price index have a positive impact on economic growth, while interest rates on loans have a negative impact. All these variables are significant at the standard level of statistical significance.

If bank loans, interest rates on loans and the consumer price index are constant, then the value of GDP will be $€ 2.46$ billion If we have an increase in bank loans by $1 \%$, keeping constant interest rates on loans and the consumer price index, then this will affect the growth of the gross domestic product by $0.32 \%$.

An increase of $1 \%$ of the interest rate on credit, keeping the amount of bank loans and the consumer price index constant, will cause a decrease in the value of GDP by $-0.18 \%$ and an increase of 1 unit in the consumer price index, while keeping other factors constant (bank loans and interest rate on credit), will affect GDP growth by $0.58 \%$.

All the analysis techniques used in the study explain that the improvement in credit volume in Kosovo has a positive effect on the GDP. And it is seen that loan interest rates have decreased in Kosovo over the years. A similar situation is valid for deposit rates. The difference between loan interest and deposit interest, which reflect the risk in the first years of Kosovo, tended to decrease until 2018. This reduces firms' production costs and reduced loan costs, allowing firms to produce more. This result also had a positive effect on GDP. The fact that the relation coefficient between interest rates and GDP is negative is proof of this. Considering the institutional and individual distribution of loans in Kosovo, one observes that the loans used by the households increased. This situation supported the increase in the total demand of the household. The positive coefficient of relationship between CPI and GDP shows that the increase in demand stimulates prices, and that rising prices encourage firms' production. According to findings, it can be said that loan mechanisms work efficiently and positively effect the GDP in Kosovo, even though one finds some reverse findings of the literature.

Based on the above results, the following recommendations are given:

Banks need to increase their credit potential, given the excessive liquidity, and this situation will further stimulate the most favorable credit offers to the two sectors of the economy (households and enterprises).

Banks need to further improve and facilitate lending conditions, such as lowering interest rates on loans, increasing credit maturity and easing the required collateral at the average level of the Western Balkan countries.

Banks should apply subsidized interest rates on loans to the agricultural and manufacturing sectors, as these are two very important branches for the country's economic development and for reducing unemployment in the country.

Commercial banks in Kosovo can reduce the margin of interest between interest rates on loans and interest rates on deposits, so that real sector enterprises, especially new ones, have a lower borrowing cost.

Given that the bank lending ratio to GDP is $41.4 \%$, the financial sector in Kosovo is still developing and this is an indication of low lending levels, even when compared to the Western Balkans average of 55\%. This shows that the banking system in Kosovo has unused (surplus) liquidity, and can afford to raise the level of $41.4 \%$ to at least $50 \%$ and to approximate with other countries in the Western Balkans region.

Commercial banks need to act more proactively to change the conservative approach of real sector enterprises, adopting more acceptable risk measurement and management practices for the real sector.

Enterprises in the real sector of the economy, especially productive and agricultural ones, must increase their professional human capacity and in the process of applying for bank loans must present ambitious and professionally argued investment plans, because this is a constant demand of banks at the time of review.

In order to support more intensively the development of the real sector, the central and local governments must allocate certain economic and financial funds, which in coordination with commercial banks will be allocated for the development of the real sector in order to increase employment.

Considering that this study contains secondary data, then during data processing we encountered difficulties in processing this data which includes larger time series, as in this study we have included only the case of Kosovo. In future studies where the impact of bank loans on economic growth in the case of Kosovo will be analyzed, to eliminate the limitation in secondary data, several other specific banking and macroeconomic factors will be taken into account, in order to explain the real effect of loans. in economic growth.

The practical implications of this study are of scientific and practical importance for advancing appropriate credit policies, which will affect the development of the real sector of Kosovo's economy. First, the study provides a theoretical and practical analysis regarding the contemporary forms of lending to the real sector and the importance of credit policy reform in the financing and development of this sector. Second, this study provides empirical evidence on how much bank loans have influenced the development of the real sector of Kosovo's economy. The evidence provided by this study could serve as a reflection of the current situation regarding the extent to which businesses in Kosovo have managed to develop through loans provided by commercial banks. The results of this study aim to influence the actions taken by financial regulators, so that their actions are oriented by the banking industry in terms of providing more favorable conditions for enterprises and an easier access to finance. through loans and for commercial banks to become a success factor for these businesses.

\section{REFERENCES}

[1] Wickell, K. (1954). Value, Capital and Rent, Rinehart, New York. https://cdn.mises.org/Value,\%20Capital,\%20and\%20Re nt 2.pdf.

[2] Cracknell, D. (2012). Policy innovations to improve access to financial services in developing countries: Learning from case studies in Kenya. Centre for Global Development.

[3] Sawyer, M. (2014). Concept paper on effects of finance on industry under different financial systems. Working Paper Series No 185.

[4] Walter, I. (2002). Financial integration across borders 
and across sectors: implications for regulatory structures. New York University Working Papers, No. S-FI-02-06.

[5] Boyreau-Debray, G. (2010). Financial intermediation and growth: Chinese style. World Bank, Development Research Group, Washington, D.C.

[6] McPherson, S.H., Waller. C. (2000). Intranational financial integration: Evidence from the Canadian banking industry. Chaper in Book Regional Aspects of Monetary Policy in Europe, 69-88. https://doi.org/10.1007/978-1-4757-6390-4_3

[7] Stiglitz, J.E., Weiss, A. (1981). Credit rationing in markets with imperfect information. American Economic Review, 71(3): 393-410.

[8] Arcand, J.L. (2015). Too much finance? Journal of Economic Growth, 20(2): 105-148. https://doi.org/10.1007/s10887-015-9115-2

[9] Chodechai, S. (2004). Determinants of Bank Lending in Thailand: An Empirical Examination for the Years 1992 - 1996, Unpublished Thesis. https://books.google.com/books/about/Determinants_of bank_lending_in_Thailand.html?id=nyK3AAAAIAAJ.

[10] Borio, C., Zhu, H. (2008). Capital regulation, risk-taking and monetary policy: A missing link in the transmission mechanism? BIS Working Papers No 268. https://www.bis.org/publ/work268.pdf.

[11] Kuttner, B.B. (2005). What explains the stock market's reaction to federal reserve policy? Journal of Finance, 60(3): 1221-1257. https://doi.org/10.1111/j.15406261.2005.00760.x

[12] Jimenez, G., Ongena, S., Peydró, J.L., Saurina, J. (2008). Hazardous times for monetary policy: What do twentythree million bank loans say about the effects of monetary policy on credit risk? Madrid: Banco de España, 82(2): 463-505. https://doi.org/10.3982/ECTA10104

[13] Altunbas, Y., Gambacorta, L., Marques-Ibanez, D. (2009). An Empirical Assessment of the An Empirical Assessment of the Risk-Taking Channel Taking Channel. BIS/ECB Workshop on "Monetary Policy and Financial Stability".

https://www.bis.org/events/conmpfs090910/altunbas.pd f.

[14] Nwakanma, P.C., Nnamdi, I.S., Omojefe, G.O. (2014). Bank credits to the private sector: Potency and relevance in Nigeria's economic growth process. Accounting and Finance $\quad$ Research, 3(2): 23-35. https://doi.org/10.5430/afr.v3n2p23

[15] Son, L., Noja, G.G., Ritivoiu, M., Tolteanu, R. (2013). Education and economic growth: An empirical analysis of interdependencies and impacts based on panel data. Timisoara Journal of Economics and Business, 6(19): 3954.

[16] Obamuyi, T.M., Edun, A.T., Kayode, O.F. (2010). Bank lending, economic growth and the performance of the manufacturing sector in Nigeria. European Scientific Journal, 8(3): 19-36.

[17] Louzis, D.P., Vouldis, A.T., Metaxas, V.L. (2010). Macroeconomic and bank-specific determinants of nonperforming loans in Greece: A comparative study of mortgage, business and consumer loan portfolios. Bank of Greece Economic Research Department - Special Studies Division, Working Paper 118.

[18] Kelly, R., McQuinn, K., Stuart, R. (2013). Exploring the steady-state relationship between Credit and GDP for a small open economy: The case of Ireland. Working Paper
Series, No 1531, European Central Ban, pp. 1-37.

[19] Caporole, G.M., Rault, C., Sova, R., Sova, A. (2009). Financial development and economic growth: Evidence from ten new EU members. International Journal of Finance and Economics, 20(1): 48-60. https://doi.org/10.1002/ijfe.1498

[20] Bezemer, D., Grydaki, M., Zhang, L. (2014). Is the financial development bad for growth? Research Report 14016-GEM, University of Groningen, Research Institute SOM (Systems, Organisations and Management).

[21] Cojocaru, L., Hoffman, S.D., Miller, B.J. (2011). Financial development and economic growth in transition economies: Empirical evidence from the CEE and CIS countries. Working paper No. 2015-04.

[22] Demirgüç-Kunt, A., Levine, R. (2008). Finance, financial sector policies, and long-run growth. Policy Research Working Paper, 4469. https://doi.org/10.1596/1813-9450-4469

[23] Huang, Y., Wang, X. (2010). Does financial repression inhibit economic growth? Empirical examination of China's reform experience. Oxford Bulletin of Economics and Statistics, 73: 833-855. https://doi.org/10.1111/j.1468-0084.2011.00677.x

[24] Petrescu, C.E., Pop, A. (2015). The influence of lending activity on economic growth in Romania. Theoretical and Applied Economics, XXII(4): 229-236.

[25] Vurur, N.S., Özen, E. (2013). The examination of the relationship between deposits bank credits and economic growth in Turkey (Türkiye'de mevduat banka kredisi ve ekonomik büyüme ilişkisinin incelenmesi-in Turkish). University of Uşak, Journal of Social Sciences (Sosyal Bilimler Dergisi), 6(3): 117-131.

[26] Garcia - Escribano, M., Han, F. (2015). Credit expansion in emerging markets: Propeller of growth? IMF Working Paper, Western Hemisphere Department. http://dx.doi.org/10.5089/9781513581927.001

[27] Awad, I.M., Karaki, M.S. (2019). The impact of bank lending on Palestine economic growth: An econometric analysis of time series data. Financial Innovation, Springer Open, 5: 14. https://doi.org/10.1186/s40854019-0130-8

[28] Hanişoğlu, G.S., Azer, O.A. (2017). The impact of housing loans on economic growth in Turkey: Times series analysis for 2010-2015 period. Emerging Markets Journal, 7(1). https://doi.org/10.5195/emaj.2017.127

[29] Cappiello, L., Kadareja, A., Sorensen, C.K., Protopapa, M. (2010). Do bank loans and credit standards have an effect on output? A panel approach for the Euro Area. Working Paper Series, No 1150, European Central Bank, pp. 1-30.

[30] Hacievliyagil, N., Eksi, I.H. (2019). A micro based study on bank credit and economic growth: Manufacturing sub-sectors analysis. South East European Journal of Economics and Business, Sciendo, 14(1): 72-91. https://doi.org/10.2478/jeb-2019-0006

[31] Ciantar, J. (2017). The impact of bank lending on economic growth in Malta. Faculty of Economics, Management and Accountancy Department of Banking and Finance, Dissertations. University of Malta.

[32] Ramírez Guerra, E.A. (2017). The economic growth and the banking credit in Mexico: Granger causality and short-term effects, 2001Q1-2016Q4. Economía Informa, 406: 46-58. 
[33] Devi, L. (2016). The impact of rural bank loans on regional economic growth and regional poverty in Indonesia. New Zealand Association of EconomistsNZAE, WP, 10: 1-25.

[34] Černohorský, J. (2017). Types of bank loans and their impact on economic development: A case study of the Czech Republic. The Journal E\&M Economics and Management (E\&M), 34-48. https://dx.doi.org/10.15240/tul/001/2017-4-003

[35] Levine, R., Zervos, S. (1998). Stock markets, banks, and economic growth. American Economic Review, 88(3): $537-558$

[36] Armeanu, D., Pascal, C., Poanta, D., Doia, C.A. (2015). The credit impact on the economic growth. Theoretical and Applied Economics, XXII(1): 5-14. http://store.ectap.ro/articole/1053.pdf.

[37] Ermişoğlu, E., Akcelik, Y., Oduncu, A. (2013). GDP growth and credit data. Working Papers 1327, Research and Monetary Policy Department, Central Bank of the Republic of Turkey.

[38] Mian, A., Sufi, A., Verner, E. (2015). Household debt and business cycles worldwide. NBER Working Paper No. 21581.

[39] Ibáñez-Hernández, F., Peña-Cerezo, M., Araujo, A. (2015). Countercyclical capital buffers: Credit-to-GDP ratio versus credit growth. Applied Economics Letters, Taylor \& Francis Journals, 22(5): 385-390. https://doi.org/10.1080/13504851.2014.946174

[40] Mamman, A., Hashim, Y.A. (2014). Impact of bank lending on economic growth in Nigeria. Research Journal of Finance and Accounting, 5(18).

[41] Vaithilingam, S., Guru, B.K., Shanmugam, B. (2014) Bank lending and economic growth in Malaysia. Journal of Asia-Pacific Business, 5(1): 51-69. https://doi.org/10.1300/J098v05n01_05

[42] Leitão, N.C. (2012). Bank credit and economic growth: A dynamic panel data analysis. Economic Research Guardian, Weissberg Publishing, 2(2): 256-267.

[43] Ananzeh, I.E. (2016). Relationship between bank credit and economic growth: evidence from Jordan. International Journal of Financial Research, 7(2): 53-63. https://doi.org/10.5430/ijfr.v7n2p53

[44] CBK. (2010). Financial Stability Report, no.1, Central Bank of Kosovo, Pristina. https://bqkkos.org/publications/financial-stability-report/?lang=en, accessed on June 10, 2020.

[45] CBK. (2011). Financial Stability Report, no.2, Central Bank of Kosovo, Pristina. https://bqkkos.org/publications/financial-stability-report/?lang=en, accessed on June 10, 2020.

[46] CBK. (2012). Financial Stability Report, no.3, Central Bank of Kosovo, Pristina. https://bqkkos.org/publications/financial-stability-report/?lang=en, accessed on June 10, 2020.

[47] CBK. (2013). Financial Stability Report, no.4, Central Bank of Kosovo, Pristina. https://bqkkos.org/publications/financial-stability-report/?lang=en, accessed on June 10, 2020.

[48] CBK. (2014). Financial Stability Report, no.5, Central Bank of Kosovo, Pristina. https://bqkkos.org/publications/financial-stability-report/?lang=en, accessed on June 10, 2020.

[49] CBK. (2015). Financial Stability Report, no.6, Central Bank of Kosovo, Pristina. https://bqkkos.org/publications/financial-stability-report/?lang=en, accessed on June 10, 2020.

[50] CBK. (2017). Financial Stability Report, Central Bank of Kosovo, Pristina. https://bqkkos.org/publications/financial-stability-report/?lang=en, accessed on June 10, 2020.

[51] CBK. (2018). Financial Stability Report, Central Bank of Kosovo, Pristina. https://bqkkos.org/publications/financial-stability-report/?lang=en

[52] CBK. (2016). Financial Stability Report, Central Bank of Kosovo, Pristina. https://bqkkos.org/publications/financial-stability-report/?lang=en, accessed on June 10, 2020.

[53] CBK. (2009). Financial Stability Report, Central Bank of Kosovo, Pristina. https:/bqkkos.org/publications/financial-stability-report/?lang=en, accessed on June 10, 2020. 